April 1990

Variation in the Annual Average Radon Concentration Measured in Homes in Mesa County, Colorado

A. S. Rood

J. L. George

G. H. Langner, Jr.
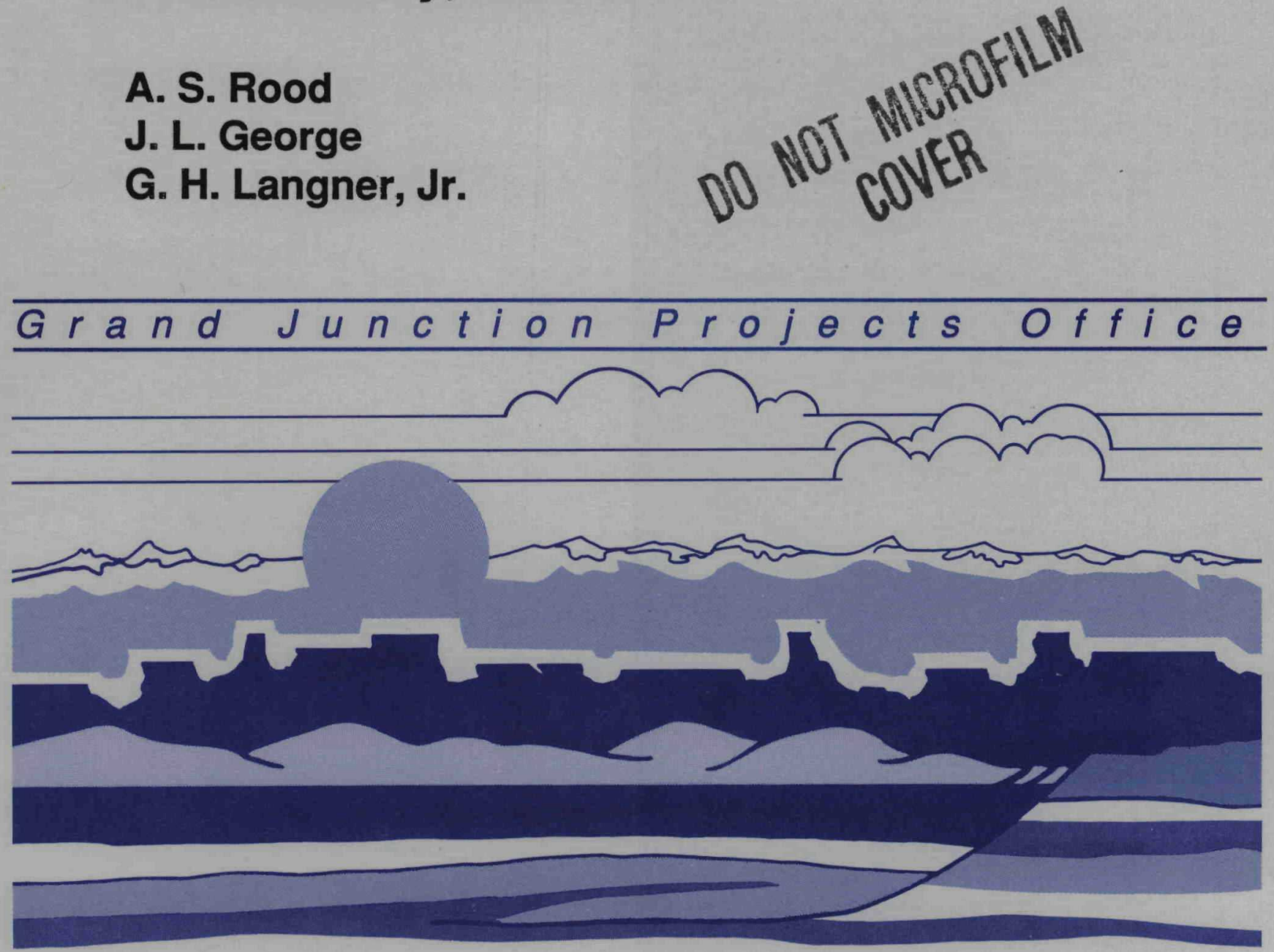

UNCGeotech

Work performed under DOE Contract No. DE-AC07-861D12584 for the U.S. Department of Energy 
This report has been reproduced from the best available copy. Printed in the United States of America. Available from:

National Technical Information Service

U.S. Department of Commerce

5285 Port Royal Road

Springfield, VA 22161

NTIS price codes

Printed copy: A03

Microfiche copy: A01

Michael K. Tucker, Manager

Grand Junction Projects Office

Larry Ball, DOE Program Manager

Grand Junction Projects Office

John R. Duray, Program Manager

Mark Pearson, Project Manager

Technical Measurements Center

This report was prepared as an account of work sponsored by an agency of the United States Government. Neither the United States Government nor any agency thereof, nor any of their employees, makes any warranty, express or implied, or assumes any legal liability or responsibility for the accuracy, completeness, or usefulness of any information, apparatus, product, or process disclosed in this report, or represents that its use would not infringe privately owned rights. Reference herein to any specific commercial product, process, or service by trade name, trademark, manufacturer, or otherwise, does not necessarily constitute or imply its endorsement, recommendation, or favoring by the United States Government or any agency thereof. The views and opinions of authors expressed hereizdo not pecessarily state or reflect those of the United States Government or any agency thereof.

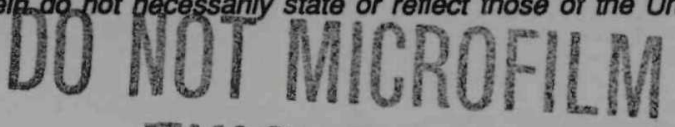




\section{DISCLAIMER}

This report was prepared as an account of work sponsored by an agency of the United States Government. Neither the United States Government nor any agency Thereof, nor any of their employees, makes any warranty, express or implied, or assumes any legal liability or responsibility for the accuracy, completeness, or usefulness of any information, apparatus, product, or process disclosed, or represents that its use would not infringe privately owned rights. Reference herein to any specific commercial product, process, or service by trade name, trademark, manufacturer, or otherwise does not necessarily constitute or imply its endorsement, recommendation, or favoring by the United States Government or any agency thereof. The views and opinions of authors expressed herein do not necessarily state or reflect those of the United States Government or any agency thereof. 


\section{DISCLAIMER}

Portions of this document may be illegible in electronic image products. Images are produced from the best available original document. 
$\mathrm{DOE} / \mathrm{ID} / 12584--57$

DE9 0007980

\title{
Variation in the Annual Average Radon Concentration Measured in Homes in Mesa County, Colorado
}

\author{
A. S. Rood \\ J. L. George \\ G. H. Langner, Jr. \\ Published April 1990 \\ UNC Geotech \\ Grand Junction, Colorado 81502 \\ Prepared for \\ U.S. Department of Energy \\ Grand Junction Projects Office \\ Under Contract No. DE-AC07-86ID12584
}

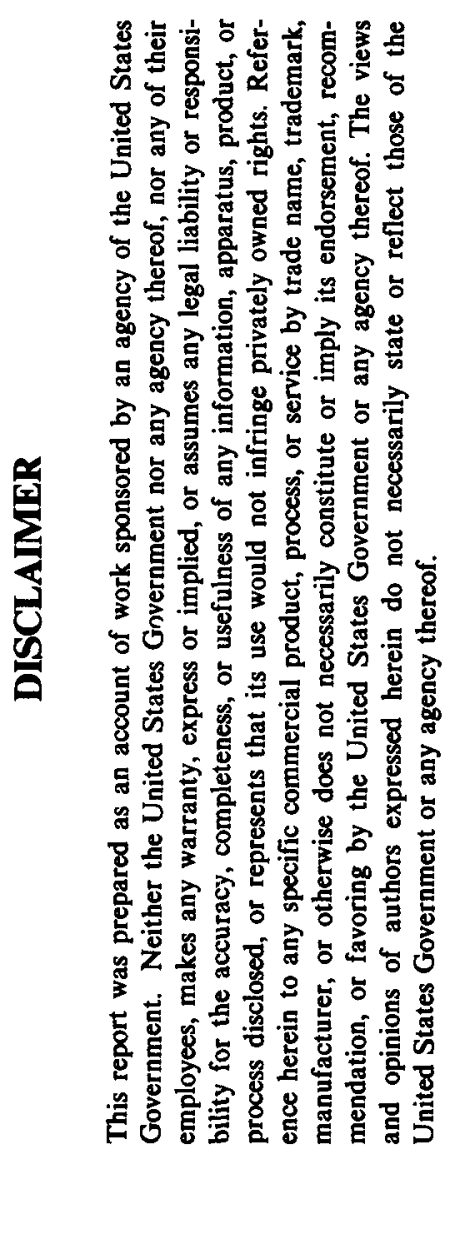




\section{Contents}

Summary $\ldots \ldots \ldots \ldots \ldots \ldots \ldots \ldots \ldots \ldots \ldots \ldots \ldots \ldots \ldots \ldots \ldots \ldots \ldots \ldots$

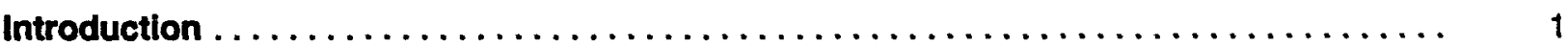

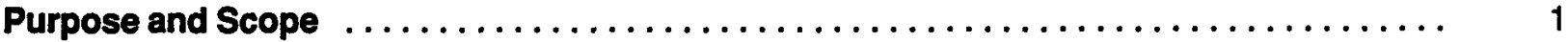

Methodology $\ldots \ldots \ldots \ldots \ldots \ldots \ldots \ldots \ldots \ldots \ldots \ldots \ldots \ldots \ldots \ldots \ldots \ldots \ldots \ldots \ldots \ldots \ldots .2$

Statistical Procedures $\ldots \ldots \ldots \ldots \ldots \ldots \ldots \ldots \ldots \ldots \ldots \ldots \ldots \ldots \ldots \ldots \ldots \ldots \ldots \ldots .4$

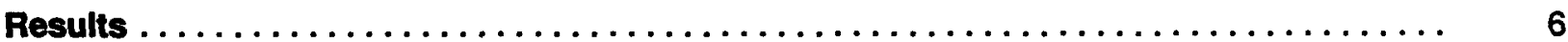

Summary and Conclusions $\ldots \ldots \ldots \ldots \ldots \ldots \ldots \ldots \ldots \ldots \ldots \ldots \ldots \ldots \ldots \ldots \ldots$

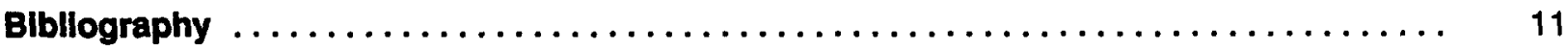

Appendix A, Field Station Monitor Data $\ldots \ldots \ldots \ldots \ldots \ldots \ldots \ldots \ldots \ldots \ldots \ldots \ldots \ldots \ldots \ldots \ldots \ldots$

Appendix B, Control Monitor Data $\ldots \ldots \ldots \ldots \ldots \ldots \ldots \ldots \ldots \ldots \ldots \ldots \ldots \ldots \ldots \ldots \ldots \ldots$

\section{Tables}

Table 1. Description of Sampling Stations Used in the Annual Average Study . ....... 3

2. Control-Monitor Sets, Batch Numbers, Exposure Periods,

Radon Studies, and Analysis Dates ....................... 4

3. Control Monitor Equivalent Background and Ratio of Terradex Results

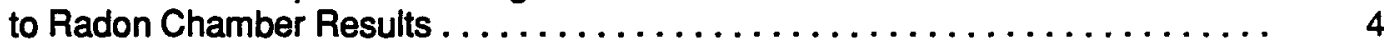

4. Calculated $t$-Values for the Paired $t$-Test Comparison Between Sampling Years.

A-1. Field Station Monitor Placement Dates and Reported Concentrations ........ . A-3

B-1. Control and Background Data for Annual Average Radon Study;

Control Set 1, 1984-1985 Data, Batch 18

B-3

B-2. Control and Background Data for Annual Average Radon Study; Control Set 2, 1985-1986 Data, Batch 18

B-4

B-3. Control and Background Data for Annual Average Radon Study; Control Set 3, 1985-1986 Data, Batch 18

B-4. Control and Background Data for Annual Average Radon Study; Control Set 4, 1985-1986 Data, Batch 12

B-5. Control and Background Data for Annual Average Radon Study; Control Set 5, 1986-1987 Data, Batch 24

B-6. Control and Background Data for Annual Average Radon Study; Control Set 6, 1987-1988 Data, Batch 24

B-7. Control and Background Data for Annual Average Radon Study; Control Set 7, 1988-1989 Data, Lot 1494 


\section{Figures}

Figure 1. Frequency Distribution of the Coefficients of Variation of the Annual Average Radon Concentration for the 30 Sampling Stations Used to Estimate the Variation in the Annual Average Radon Concentration .

2. Normal Probability Plot of the Coefficients of Variation of the Annual Average

Radon Concentrations for the 30 Sampling Stations Used to Estimate the

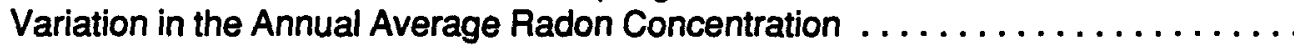

3. Five-Year-Average Radon Concentrations in the Basement Versus 5 -Year-Average Radon Concentrations on the First Floor . . . . . . . . . . 


\section{Summary}

The Technical Measurements Center (TMC) has measured annual average indoor radon concentrations at 49 sampling stations in 33 residential structures over a 5-year period for the purpose of determining the year-to-year variation in the annual average radon concentration in homes in Mesa County, Colorado. One to three Terradex ${ }^{*}$ Track Etch ${ }^{\circledR}$ Type SF radon monitors were deployed for 1-year periods at each sampling location. The structures used in the study were representative of middleincome families.

Thirty of the 49 sampling stations had complete data for the 5-year study period. These data were used to determine the variation in the annual average radon concentration. Monitor results were checked by exposing randomly selected monitors to known radon concentrations in the U.S. Department of Energy Grand Junction Projects Office (DOE/GJPO) radon chamber. These control monitors were used to correct bias due to changes in monitor processing and to determine the uncertainty inherent in the alpha track monitor. Based on the results of the control monitors, the uncertainty in a 1-year-long measurement using two Track Etch $^{\circledR}$ Type SF monitors was 11.3 percent.

Variation in the annual average radon measurement at each sampling station was expressed in terms of the coefficient of variation (standard deviation/mean). The 5-year mean radon concentration, standard deviation, and coefficient of variation were calculated for each sampling station. Average variation in the annual average radon measurement was determined by calculating the mean sampling station coefficient of variation.
The range of radon concentrations measured in the 30 sampling stations with 5 years of data was between $7.4 \mathrm{~Bq} / \mathrm{m}^{3}(0.20 \mathrm{pCi} / \mathrm{L})$ and 444 $\mathrm{Bq} / \mathrm{m}^{3}(12 \mathrm{pCi} / \mathrm{L})$ with an arithmetic mean of $96 \mathrm{~Bq} / \mathrm{m}^{3}(2.6 \mathrm{pCi} / \mathrm{L})$. Coefficients of variation for these 30 sampling stations ranged from 6.4 to 46 percent with an arithmetic mean of 25 percent.

The variability inherent in the radon measurement using Track Etch ${ }^{\circledR}$ Type SF radon monitors (11.3 percent) was factored out of the observed measured variability (i.e., 25 percent assuming normal statistics) to obtain the variability in the annual average radon concentration. This variation was 22 percent.

Basement radon concentrations were higher than ground-level or first-floor radon concentrations in all cases. The coefficients of variation for first-floor 5-year-average radon concentrations were not significantly different from the coefficients of variation for the basement 5-year-average radon concentrations.

Results from this study should only be considered applicable to structures that are (1) similar to those used in this study, (2) located in a climatic and geologic environment similar to Mesa County, Colorado, and (3) found to be within the range of radon concentrations measured in the structures of this study. The results indicate that variation in the annual average radon concentration is slightly greater than variation inherent in the alpha track monitor used in this study.

This is a continuing study, and this report presents the data that have been collected and processed to date.

"Terradex Corporation, 2 Science Road, Glenwood, Illinois, 60425-1586. 


\section{Variation in the Annual Average Radon Concentration Measured in Homes in Mesa County, Colorado}

\section{Introduction}

The U.S. Department of Energy (DOE) Office of Remedial Action and Waste Technology (formerly the Division of Remedial Action Projects) established the Technical Measurements Center (TMC) in 1982 at the Grand Junction, Colorado, Projects Office (GJPO), which is operated by UNC Geotech (UNC). The mission of the TMC is to provide standardization, calibration, comparability, verification of data, quality assurance, and cost-effectiveness for the environmental measurement requirements of DOE remedial action programs.

The estimation of annual average radondaughter concentrations (RDC) within structures located on properties designated for remedial action is one measurement requirement of remedial action programs. Various methods of estimating annual average RDC methods have been evaluated by the TMC using two criteria: (1) does the method provide reasonable assurance of compliance with the clean-up standards, and (2) does the method minimize the cost of verification. Approved methods include year-long alpha-track measurements, "prompt" alpha-track measurements, intermittent measurements (i.e., a 1-week sample approximately every other month for 1 year) using radon-progeny integrating sampling units (RPISUs), and an abbreviated RPISU method. The alpha-track devices measure radon rather than radon daughters. The assumption is made that airborne radon daughters on the average are in 50-percent equilibrium with radon, thus the conversion from radon concentration to $R D C$ can be made.

All of the approved methods estimate the annual average RDC in a structure during one particular year, while in reality the measurement of choice would be an estimate of the average RDC over the lifetime of the structure. Some factors that affect the average radon concentration over the lifetime of the structure are location, type, age, condition, climate, number of occupants, and occupant life-style.
Practical considerations limit the remedial action programs to a 1-year estimate of the lifetime annual average RDCs in structures. However, the error introduced by substituting a 1-year annual average RDC estimate for a lifetime estimate has never been determined due to a lack of appropriate data. The TMC has performed indoor annual average radon measurements from a group of residential structures in Mesa County, Colorado, for several years for the purpose of examining the variability of radon in structures from year to year, and comparing the year-to-year variability with the error associated with the various approved methods of estimating annual average RDCs. The error associated with using a 1-year radon measurement as an estimate of the RDC over the lifetime of the structure may be estimated from these data.

\section{Purpose and Scope}

The purpose of this study is to examine the variability in the annual average indoor radon concentration. The TMC has been collecting annual average radon data for the past 5 years in 33 residential structures in Mesa County, Colorado. This report is an interim report that presents the data collected up to the present. Currently, the plans are to continue this study in the future.

Five years of data exist for stations 1 through 44 (from 1984 to 1989), excluding stations $3,4,15,18,21,24,25,29,34,35,40$ and 41. Four years of data exist for stations 45 through 56 (from 1985 to 1989). Terradex Track Etch ${ }^{\circledR}$ Type SF radon monitors were used to measure the radon concentrations at the sampling stations. Some of the data were originally collected as subsets of other TMC field studies. The 1984-85 data for stations 1 through 44 were collected for the "Field Study of Indoor Average Radon-Daughter Estimation Methods" (George and Langner, 1986). The first 1985-86 (85-86a) data for stations 1 through 44 were collected for the "Comparison 
of Radon and Radon-Daughter Grab Samples Obtained During the Winter and Summer" (Karp, 1987). The second 1985-86 (85-86b) data for stations 1 through 56 were collected for the "Validation of the Prompt Alpha-Track Method" (George and Langner, 1987). Subsequent annual data were collected specifically for this study.

Brief descriptions of the sampling stations are listed in Table 1. These stations were not randomly selected, but chosen on the basis of accessibility. Station numbers and structure designations correspond to those used in TMC reports cited above. Stations 3, 4, 15, 34, 35, 40, and 41 were omitted from Table 1 because the data sets from the structures housing these stations are incomplete. The occupants are no longer participating in TMC field studies. As a consequence, the numbering of the 49 stations goes up to 56 because these station numbers were not repeated.

\section{Methodology}

Track Etch ${ }^{\circledR}$ Type SF alpha-track monitors, manufactured and processed by Terradex Corporation, were used in this study. The number of monitors deployed each year at each station varied from one to three, depending on the sample design of the study in progress at the time. On the average, two monitors per sampling station have been deployed on an annual basis. Future deployments will consist of two radon monitors at each sampling station. At each station, the monitors were attached to a paper spindle using adhesive clips. After retrieval, the monitors were processed by Terradex at the 0.2-picocurie-month-per-liter sensitivity, which is the most sensitive processing offered by Terradex.

The exposure interval for each monitor was approximately 1 year. The exact dates of placement are found in Appendix A. The batch or lot numbers of detector material used each year for the monitors are listed in Table 2.

Approximately 15 randomly selected monitors per year (see Appendix B) were used for quality control and as a correction to normalize measurement data from year-to-year differences in monitor processing and detector material. In addition, these monitors were used as a measure of the variation inherent in monitors. The quality-control monitors were 'exposed to known radon concentrations in the Alpha-Track Radon Calibration Chamber and Radon/Radon-Daughter Environmental Chamber at the GJPO. The radon concentrations during each exposure were monitored with an Eberline RGM-2 continuous radon monitor and verified by collecting grab samples using zinc-sulfide scintillation cells. The calibrations are traceable to the U.S. National Institute of Standards and Technology. Control-monitor exposures were designed to simulate exposures in the field. Radon exposure in the sampling stations ranged from $2.7 \mathrm{kBq}-\mathrm{d} / \mathrm{m}^{3}$ to $162 \mathrm{kBq}$ $\mathrm{d} / \mathrm{m}^{3}$ (73 to $4380 \mathrm{pCi}-\mathrm{d} / \mathrm{L}$ ). Most control monitors were returned to Terradex with the fieldstation detectors, which reported a 1-year exposure period. Actual exposure periods for the control monitors were from 7 to 10 days in the radon chamber, and yielded total integrated exposures similar to the monitors exposed in the field.

In addition to the 15 control monitors, 4 to 7 unexposed monitors were submitted with the field-station monitors for processing. These unexposed monitors served as the background exposure correction for both the field and control monitors.

Field data were corrected by subtracting an equivalent background concentration from the Terradex-reported concentration and dividing the result by a calibration factor. The equivalent background concentration was the reported background concentration normalized by the actual exposure time each field detector received (approximately 365 days). For most control sets, the field-exposure time was reported as the exposure time for background monitors; thus, no correction was needed. Background-monitor results that had reported exposure time of less than field-exposure time were normalized by multiplying them by the ratio of the reported-exposure time to fieldexposure time (i.e., reported number of exposure days/number of field exposure days).

The correction factor for field measurements was calculated as follows:

1. The total background exposure for the control set was calculated in units of $\mathrm{pCi}-\mathrm{d} / \mathrm{L}$. 
Table 1. Description of Sampling Stations Used in the Annual Average Study

\begin{tabular}{|c|c|c|c|}
\hline Station No. & Structure $e^{\mathrm{a}}$ & Room Sampled & Level Sampledb \\
\hline 1 & A & Storage & 0 \\
\hline 2 & A & Dining Room & 1 \\
\hline 5 & $\mathrm{C}$ & Living Room & 1 \\
\hline 6 & D & Family Room & 0 \\
\hline 7 & E & Bedroom & 1 \\
\hline 8 & E & Storage & 0 \\
\hline 9 & $\mathbf{F}$ & Bedroom & 1 \\
\hline 10 & $\mathbf{G}$ & Living Room & 1 \\
\hline 11 & $\mathbf{G}$ & Rec Room & 0 \\
\hline 12 & H & Bedroom & 0 \\
\hline 13 & H & Living Room & 1 \\
\hline 14 & 1 & Family foom & 1 \\
\hline 16 & K & Rec Room & 1 \\
\hline 17 & L & Bedroom & 1 \\
\hline 18 & $\mathbf{M}$ & Family Room & 0 \\
\hline 19 & $\mathbf{N}$ & Living Room & 1 \\
\hline 20 & $\mathbf{N}$ & Shop & 0 \\
\hline 21 & 0 & Utility & 0 \\
\hline 22 & 0 & Bedroom & 1 \\
\hline 23 & $\mathbf{P}$ & Dining Room & 1 \\
\hline 24 & $\mathbf{P}$ & Shop & 1 \\
\hline 25 & $\mathbf{Q}$ & Family Room & 1 \\
\hline 26 & $\mathbf{R}$ & Library & 1 \\
\hline 27 & R & Bedroom & 0 \\
\hline 28 & $\mathbf{s}$ & Rec Room & 1 \\
\hline 29 & $T$ & Sewing Room & 1 \\
\hline 30 & $T$ & Utility/Storage & 0 \\
\hline 31 & U & Living Room & 1 \\
\hline 32 & $\mathrm{U}$ & Family Room & 0 \\
\hline 33 & v & Family Room & 1 \\
\hline 36 & $x$ & Utility & 0 \\
\hline 37 & $x$ & Dining Room & 1 \\
\hline 38 & $Y$ & Dining Room & 1 \\
\hline 39 & $\mathbf{Y}$ & Family Room & 0 \\
\hline 42 & AA & Dining Room & 1 \\
\hline 43 & BB & Rec Room & 0 \\
\hline 44 & BB & Bedroom & 2 \\
\hline 45 & $\mathrm{CC}$ & Bedroom & 1 \\
\hline 46 & DD & Bedroom & 1 \\
\hline 47 & DD & Utility & 0 \\
\hline 48 & EE & Enclosed Patio & 1 \\
\hline 49 & FF & Bedroom & 1 \\
\hline 50 & FF & Utility & 0 \\
\hline 51 & GG & Utility & 1 \\
\hline 52 & HH & Bedroom & 1 \\
\hline 53 & II & Bedroom & 1 \\
\hline 54 & JJ & Living Room & 1 \\
\hline 55 & JJ & Bedroom & 0 \\
\hline 56 & KK & Living Room & 1 \\
\hline
\end{tabular}

A letter code was assigned to each structure housing sampling stations. Note that a single structure may have more than one station.

The codes used to designate the level sampled are as follows: $0=$ basement or lowest floor of split level; 1 = first floor; 2 = second floor. 
Table 2. Control-Monitor Sets, Batch Numbers, Exposure Periods, Radon Studies, and Terradex Analysis Dates

\begin{tabular}{ccccc}
\hline $\begin{array}{c}\text { Control } \\
\text { Set }\end{array}$ & $\begin{array}{c}\text { Batch } \\
\text { Number }\end{array}$ & $\begin{array}{c}\text { Exposure } \\
\text { Period }\end{array}$ & $\begin{array}{c}\text { Radon } \\
\text { Study }\end{array}$ & $\begin{array}{c}\text { Terradex } \\
\text { Analysis Date }\end{array}$ \\
\hline 1 & 18 & $1984-1985$ & Indoor Field Study & - \\
2 & 18 & $1985-1986$ & Grab Sample Study & $04 / 21 / 86$ \\
3 & 18 & $1985-1986$ & Grab Sample Study & $05 / 28 / 86$ \\
4 & 12 & $1985-1986$ & Prompt Alpha Track & $08 / 06 / 86$ \\
5 & 24 & $1986-1987$ & Annual Average Study & $07 / 27 / 87$ \\
6 & 24 & $1987-1988$ & Annual Average Study & $07 / 29 / 88$ \\
7 & $1494^{a}$ & $1988-1989$ & Annual Average Study & $08 / 04 / 89$ \\
\hline
\end{tabular}

Lot number.

2. The total Terradex-reported exposure for the control set was calculated in units of $\mathrm{pCi}-\mathrm{d} / \mathrm{L}$.

3. The total background exposure was subtracted from the total Terradexreported exposure to yield the total reported net exposure.

4. The total actual exposure (as measured in the Alpha-Track Radon Calibration Chamber) for the control set was calculated (pCi-d/L).

5. The ratio of the total reported net exposure to the total actual exposure was the correction factor.

Control monitors were divided into seven sets based on batch number, exposure period, radon study, and analysis date (see Table 2 ).

A correction factor and background concentration were calculated for each control set. The equivalent background concentration was subtracted from the field-station-reported concentration, and the results were divided by the appropriate correction factor to obtain a corrected radon concentration. Control-monitor correction factors and equivalent background concentrations are summarized in Table 3.

\section{Statistical Procedures}

Two statistical procedures were performed in this study. The first procedure was a paired $t$-test to determine if annual average radon concentrations were systematically and significantly different from one year to the next. The second procedure was an estimation of the variability in the annual average indoor radon concentration in the residential structures monitored.

Annual radon measurements were made at 49 stations; however, only 30 of the stations had complete data for the 5-year time period (i.e., February, 1984 to July, 1989). Only those stations that had complete data for the 5-year time period were included in the estimation of

Table 3. Control Monitor Equivalent Background and Ratio of Terradex Results to Radon Chamber Results

\begin{tabular}{cccc}
\hline $\begin{array}{c}\text { Control } \\
\text { Set }\end{array}$ & \multicolumn{2}{c}{$\begin{array}{c}\text { Equivalent Background } \\
\left(\mathbf{B q} / \mathbf{m}^{3}\right)\end{array}$} & $\begin{array}{c}\text { Correction } \\
\text { Factor }\end{array}$ \\
\hline 1 & 4.1 & 0.11 & 1.04 \\
2 & 3.0 & 0.08 & 0.98 \\
3 & 4.4 & 0.12 & 0.99 \\
4 & 2.6 & 0.07 & 0.82 \\
5 & 2.2 & 0.06 & 1.00 \\
6 & 4.1 & 0.11 & 0.89 \\
7 & 6.3 & 0.17 & 0.72 \\
\hline
\end{tabular}


the variability in the annual average radon concentration. Sample stations with incomplete 5 -year data were included in determination of significant systematic year-to-year differences in the annual average radon concentration. For example, sampling station 34 had data for the 1984-85 and 1985-86 sampling periods. Data from subsequent years were lacking. This station was not included in estimation of the variability in the annual average radon concentration, but was used in the determination of significant systematic year-to-year differences in the annual average radon concentration between the 1984-85 and 1985-86 measurement periods.

A paired t-test was used to determine significant year-to-year differences in annual average radon concentrations. In a paired t-test, the mean difference between sample pairs is computed. The sample pairs in this case were the annual average radon concentrations of adjacent years. The $t$-value is given by

$$
t=\frac{X_{d}}{s_{e}},
$$

where

$$
\begin{aligned}
X_{d}= & \text { the mean difference, and } \\
S_{e}= & \text { the standard error of the } \\
& \text { mean difference. }
\end{aligned}
$$

The standard error of the mean difference is given by

$$
\mathrm{se}_{\mathrm{e}}=\frac{\mathrm{s}}{\mathrm{n}^{1 / 2}}
$$

where

$$
\begin{aligned}
\mathbf{s}= & \text { the standard deviation of the } \\
& \text { mean difference, and } \\
\mathbf{n}= & \text { the number of sample pairs. }
\end{aligned}
$$

This value was computed and compared with the tabulated $t$-value.

Variability in the annual average radon measurement was determined by calculating the mean and standard deviations of the radon con centration for each monitoring station during the 5-year study period. Measurements were taken for two time periods during 1985 and 1986. The first time period was from February, 1985 to February, 1986 (85-86a). The second time period was from July, 1985 to July, 1986 (85-86b). The mean and standard deviation of the radon concentration was calculated for the 5-year data set using the 85-86a radon data and, again, using the 85-86b radon data:

$$
\begin{gathered}
M a_{i}=\frac{(84-85)+(85-86 a)+(86-87)+(87-88)+(88-89)}{5}, \\
M b_{i}=\frac{(84-85)+(85-86 b)+(86-87)+(87-88)+(88-89)}{5},
\end{gathered}
$$

where

$$
\begin{aligned}
(84-85)= & \text { the annual average radon } \\
& \text { concentration for the } 1984 \text { to } \\
& 1985 \text { period, } \\
\mathrm{Ma}_{\mathrm{i}}= & \text { the mean radon concentration } \\
& \text { for station } \mathrm{i} \text { calculated using the } \\
& 85-86 \mathrm{a} \text { data, and } \\
\mathrm{Mb}_{\mathrm{i}}= & \text { the mean radon concentration } \\
& \text { for station } \mathrm{i} \text { calculated using the } \\
& \text { 85-86b data. }
\end{aligned}
$$

The standard deviations (i.e., $\mathrm{Sa}_{\mathrm{i}}$ and $\mathrm{Sb}_{\mathrm{i}}$ ) were similarly calculated for the two 5-year data sets. The two 5-year mean radon concentrations and standard deviations were then averaged to yield a single mean and standard deviation of the radon concentration for each station over the 5-year study period:

$$
\begin{aligned}
\mathrm{M}_{\mathbf{i}} & =\left(\mathrm{Ma}_{\mathrm{i}}+\mathrm{Mb}_{\mathrm{i}}\right) / 2 \text {, and } \\
\mathrm{S}_{\mathrm{i}} & =\left(\mathrm{Sa}_{\mathrm{i}}+\mathrm{Sb}_{\mathrm{i}}\right) / 2 .
\end{aligned}
$$

The coefficient of variation was calculated:

$$
C V_{i}=S_{i} / M_{i},
$$

where

$$
\begin{aligned}
\mathrm{M}_{\mathrm{i}}= & \text { the mean radon concentration } \\
& \text { for station } \mathrm{i} \text { using both } 85-86 \\
& \text { data sets, } \\
\mathrm{S}_{\mathrm{i}}= & \text { the standard deviation for } \\
& \text { station } \mathrm{i} \text { using both } 85-86 \\
& \text { data sets, and } \\
\mathrm{CV}_{\mathrm{i}=}= & \text { coefficient of variation } \\
& \text { for station } \mathrm{i} .
\end{aligned}
$$

The mean coefficient of variation (MCV) was then calculated for all the stations:

$$
M C V=\frac{\sum_{i=1}^{30} C V_{i}}{30} .
$$


The mean coefficient of variation represents the total variation observed when performing an annual average radon measurement. This variation consists of two main sources: (1) variation inherent in the radon monitor (i.e., counting statistics and detector processing) and (2) actual variation in annual average radon concentrations.

The sources of variation in the annual average radon concentrations include variation caused by environmental and meteorological conditions, condition and age of the residential structure, and occupant behavior and life-style. Significant meteorological changes resulting in significant changes in radon concentration would be reflected in the significant systematic year-to-year differences in the annual average radon concentration.

Variations in the annual average radon concentrations were calculated by subtracting the variation inherent in the measurement from the total observed variation. The total variation can be expressed as the sum of the squares of the various components:

$$
V_{t}^{2}=V_{m}^{2}+V_{t}^{2}
$$

where

$$
\begin{aligned}
V_{t}= & \text { total variation, } \\
V_{m}= & \text { variation inherent in the } \\
& \text { measurement, and } \\
V_{r}= & \begin{array}{l}
\text { variation in the annual average } \\
\text { radon concentration. }
\end{array}
\end{aligned}
$$

Variation in the annual average radon concentration can be obtained from Equation (9) by solving for $\mathrm{V}_{\mathrm{r}}$.

\section{Results}

The 5-year mean and standard deviation of the radon concentrations for each of the 30 stations were calculated. Observed annual average radon concentrations ranged from 7.4 $\mathrm{Bq} / \mathrm{m}^{3}$ to $444 \mathrm{~Bq} / \mathrm{m}^{3}(0.20$ to $12 \mathrm{pCi} / \mathrm{L})$ with a mean of $96 \mathrm{~Bq} / \mathrm{m}^{3}(2.6 \mathrm{pCi} / \mathrm{L})$. The coefficients of variation ranged from 6.4 to 46.3 percent with a mean of 25 percent. A frequency distribution of the coefficients of variation shows that these data appear to be somewhat bimodal (see Figure 1). However, for this study, the data were assumed to be normally distributed.
A normal probability plot (see Figure 2) indicates the data generally follow a normal distribution.

The mean coefficient of variation for the control detector results in the $2.7-$ to- $162-\mathrm{kBq}-\mathrm{d} /$ $\mathrm{m}^{3}$ (73-to-4380-pCi-d/L) exposure range was 16 percent. Other investigators (Pearson, 1989) reported an observed mean coefficient of variation in Track Etch ${ }^{\otimes}$ Type SF detectors of 39 percent for an exposure of $4.4 \mathrm{kBq}-\mathrm{d} / \mathrm{m}^{3}$. Nelson (1987) observed coefficients of variation for Track Etch Type F detectors ranging from 14 to 45 percent for detectors in the 6.6 to 129 $\mathrm{kBq}-\mathrm{d} / \mathrm{m}^{3}$ exposure range. The coefficient of variation in any nuclear counting device is a function of the number of events that are recorded; the greater the number of events, the lower the coefficient of variation as predicted by counting statistics. This relationship was not observed in the control samples used in this study. Pearson (1989) also noted this lack of correlation between observed and predicted variation when he compared predicted and observed coefficients of variation for Terradex Track Etch Type SF detectors. This lack of correlation between theoretical and observed coefficients of variation suggests additional systematic and random uncertainties in the detector processing procedure.

The mean coefficient of variation (i.e., 16 percent) in the control detectors represents the uncertainty inherent in a single alpha track measurement. The uncertainty in a measurement using $n$ number of monitors is given by the standard error of the mean:

$$
s_{e}=s_{d} /(n)^{1 / 2},
$$

where

$$
\begin{aligned}
& s_{e}= \text { standard error of the mean } \\
& \text { in } n \text { number of alpha track } \\
& \text { measurements, and } \\
& s_{d}= \text { standard deviation of a single } \\
& \text { alpha track measurement. }
\end{aligned}
$$

On the average, two monitors per sampling station were deployed. Thus, for the purpose of this report, $n$ was assumed to be 2 and se was calculated to be 11.3 percent.

The variation in the measurement of the annual average radon concentration is a function of both the variation of the radon concen- 


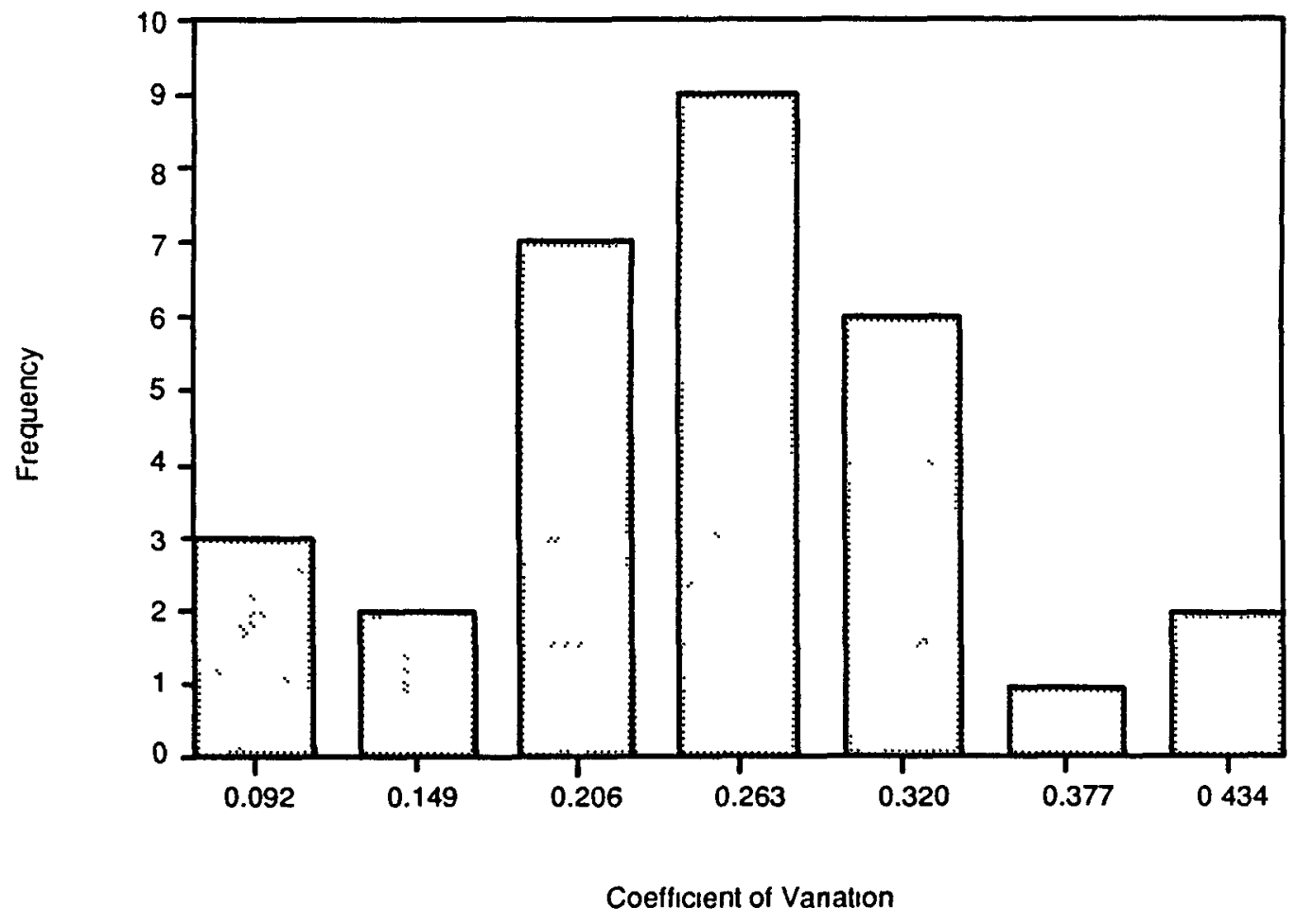

Figure 1. Frequency Distribution of the Coefficients of Variation of the Annual Average Radon Concentrations for the 30 Sampling Stations Used to Estimate the Variation in the Annual Average Radon Concentration

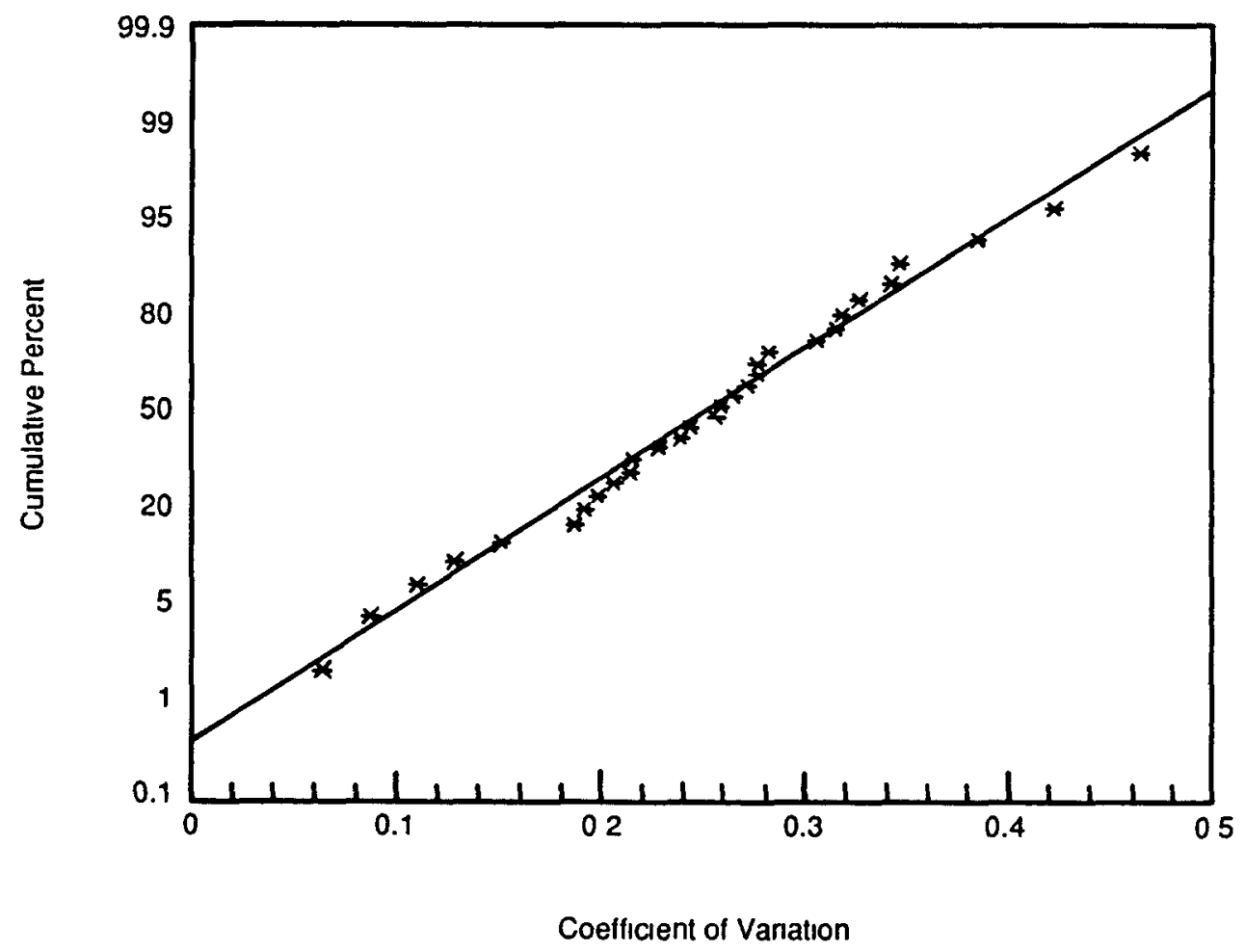

Figure 2. Normal Probability Plot of the Coefficients of Variation of the Annual Average Radon Concentrations for the 30 Sampling Stations Used to Estimate the Variation in the Annual Average Radon Concentration 
tration in the house and the variation inherent in the measurement. The variation inherent in the measurement was represented by the average variation in the alpha track control monitors. The annual average variation in radon concentration was calculated using Equation (9), solving for $V_{r}$, and substituting 25 percent for $V_{t}$. The average variation in annual radon concentration was calculated to be 22 percent.

Annual average radon concentrations were observed to be higher in the basement sampling stations than in the first-floor or groundlevel sampling stations. The mean radon concentration in first-floor sampling stations was $76 \mathrm{~Bq} / \mathrm{m}^{3}(2.06 \mathrm{pCi} / \mathrm{L})$ while the mean radon concentration in basement sampling stations was $130 \mathrm{~Bq} / \mathrm{m}^{3}$ (3.51 $\left.\mathrm{pCi} / \mathrm{L}\right)$. A plot of the basement 5-year-average radon concentration versus the first-floor 5-year-average radon concentration for structures with sampling stations in both the basement and on the first floor (see Figure 3) shows a positive relationship between basement and first-floor 5 -year-average radon concentration.
The mean coefficient of variation of the 5-year-average radon concentration in the basement (0.238) was slightly lower than the mean coefficient of variation of the 5-year-average radon concentration on the first floor (0.256). A t-test showed that this difference was not significant.

A paired t-test was performed on the yearto-year data in order to determine if significant variation occurred between years included in the study. The null hypothesis (Ho) for this analysis was

$$
\text { Ho: } u_{i}=u_{j} \text {, }
$$

where

$$
\begin{aligned}
& u_{i}= \text { the mean radon concentration } \\
& \text { for all the sampling stations } \\
& \text { for year } i \text {, and } \\
& u_{j}= \text { the mean radon concentration } \\
& \text { for all the sampling stations for } \\
& \text { year } j .
\end{aligned}
$$

If the calculated $t$-value is greater than the tabulated $t$-value then $H_{0}$ is rejected.

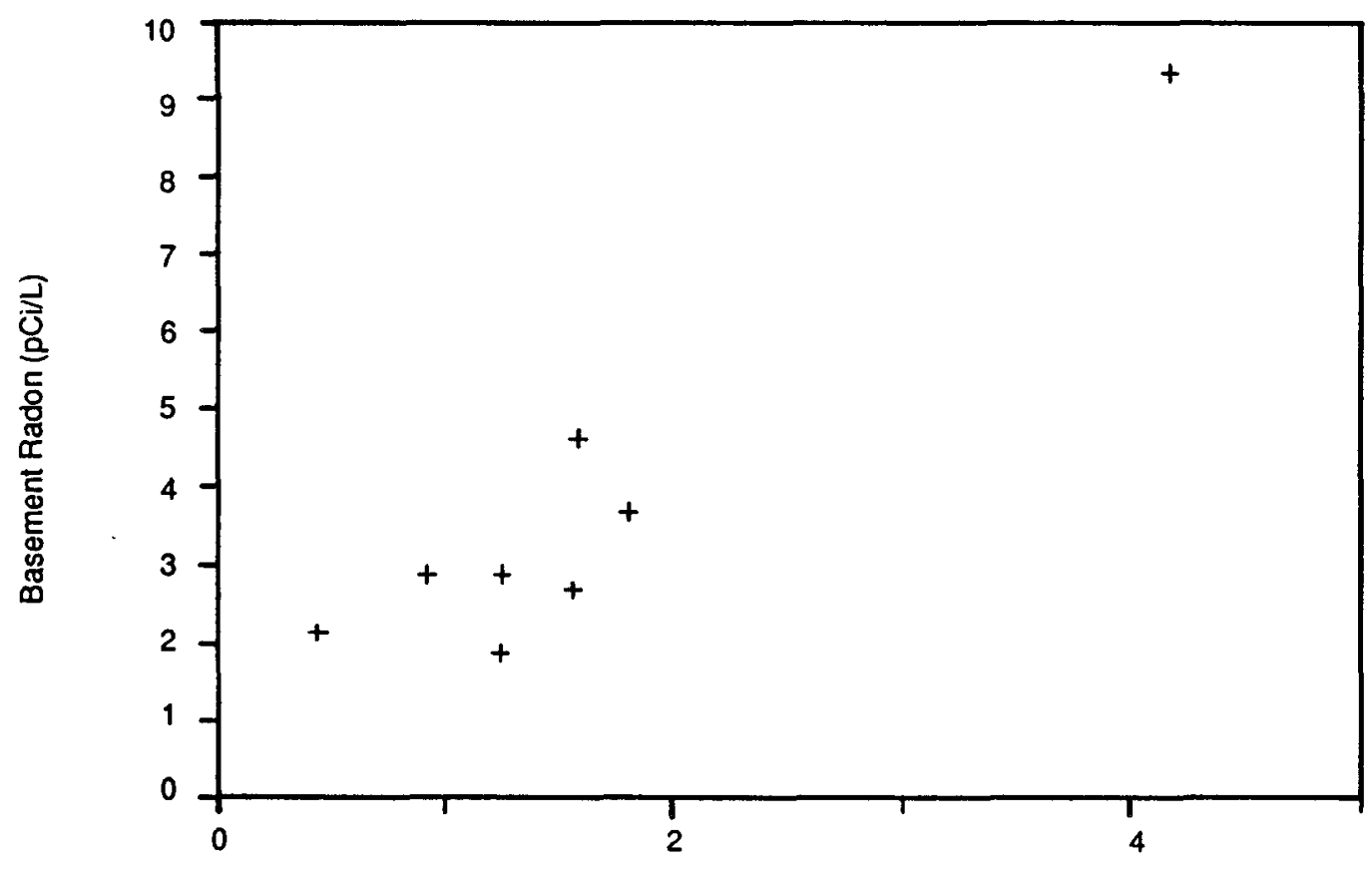

1st Floor Radon (pCi/L)

Figure 3. Five-Year-Average Radon Concentrations in the Basement Versus 5-Year-Average Radon Concentrations on the First Floor 
Calculated $t$-values for year-to-year comparisons (see Table 4) indicated the 1987-88 measurement period was significantly different from all other measurement periods (at the 90to-95-percent confidence level). The 1988-89 measurement period was also significantly different from the 1985-86a measurement period and from the 1984-85 measurement period. The 1987-88 measurement period had the highest average $\left(109 \mathrm{~Bq} / \mathrm{m}^{3}, 2.98 \mathrm{pCi} / \mathrm{l}\right)$ radon concentration for the six measurement periods included in the study.

Detailed investigation into why these years were significantly different from one another was beyond the scope of this report. However, significant differences observed between the year-to-year radon concentrations would suggest the following:

1. A change in one of the radon-influencing factors that would affect all homes measured in this study, such as weather.

2. A variable year-to-year bias that has gone undetected in the radon measurement process.

\section{Summary and Conclusions}

Houses in Mesa County show a year-to-year variability in radon concentration of 22 percent. The observed mean coefficient of variation (including the variation inherent in the mea- surement) was 25 percent. The distribution of observed coefficients of variation appeared to be somewhat bimodal; however, normal statistics were used in the analysis. The yearto-year variability in the annual average radon concentrations was slightly greater than the observed variation inherent in the alpha track monitors.

The average radon concentration for the measurement period 1987-88 was significantly different from all other measurement periods. Also, the measurement period 1988-89 was significantly different from the $1984-85$ and 1985$86 \mathrm{a}$ measurement periods. One of the factors that is likely to affect the annual average radon concentration for all structures during a measurement period is meteorology. In future work, the correlation between annual average meteorological parameters (i.e., wind-speed, barometric pressure, etc.) and the annual average radon concentration will be examined.

Variability in basement radon concentrations was not significantly different from variability in first-floor radon concentrations. This observation suggests that the factors that affect variability in the annual average radon concentration affect the structure as a whole.

The structures used as sampling stations in this study were representative of middleincome families. Results from this study should only be considered applicable to structures

Table 4. Calculated $t$-Values for the Paired $t$-Test Comparison Between Sampling Years

\begin{tabular}{|c|c|c|c|c|}
\hline \multirow{2}{*}{$\begin{array}{c}\text { Years } \\
\text { Comparison }\end{array}$} & \multirow{2}{*}{$\begin{array}{l}\text { Number of } \\
\text { Samples }\end{array}$} & \multirow{2}{*}{$\begin{array}{l}\text { Calculated } \\
\text { t-Value }\end{array}$} & \multicolumn{2}{|c|}{ Published Value $^{a}$} \\
\hline & & & $\mathbf{P}$ & $t$ \\
\hline $84-85$ to $85-86 a$ & 40 & 0.936 & 0.100 & 1.282 \\
\hline $84-85$ to $85-86 b$ & 35 & 1.070 & 0.050 & 1.645 \\
\hline $84-85$ to $86-87$ & 30 & 0.021 & 0.025 & 1.960 \\
\hline $84-85$ to $87-88$ & 30 & 1.780 & 0.010 & 2.326 \\
\hline $84-85$ to $88-89$ & 32 & 1.540 & 0.005 & 2.576 \\
\hline $85-86 a$ to $85-86 b$ & 35 & 0.011 & & \\
\hline $85-86 a$ to $88-89$ & 28 & 1.480 & & \\
\hline $85-86 a$ to $87-88$ & 34 & 2.220 & & \\
\hline $85-86 b$ to $86-87$ & 46 & 0.270 & & \\
\hline $85-86 b$ to $87-88$ & 41 & 1.420 & & \\
\hline $86-87$ to $87-88$ & 41 & 1.530 & & \\
\hline $87-88$ to $88-89$ & 40 & 1.500 & & \\
\hline
\end{tabular}

\footnotetext{
aFrom Mendenhall and Sheaffer, 1973, for $n>30$.
} 
similar to those used in this study; that is, structures located in a climatic and geologic environment similar to Mesa County,

Colorado, and found to have the range of radon concentrations measured in this study's structures.
This is an ongoing study, and this report presents the data that have been acquired to date. Currently, the plans are to continue this study in the future. 


\section{Bibliography}

George, J.L., and G.H. Langner, Jr., 1986. Field Study of Indoor Average Radon-Daughter Estimation Methods, GJ/TMC-26, U.S. Department of Energy, Technical Measurements Center, Grand Junction, Colorado.

George, J.L., and G.H. Langner, Jr., 1987. Validation of the Prompt Alpha-Track Method, UNC/GJ-33, U.S. Department of Energy, Technical Measurements Center, Grand Junction, Colorado.

Karp, K.E., 1987. Comparison of Radon and Radon-Daughter Grab Samples Obtained During the Winter and Summer, UNC/GJ-29, U.S. Department of Energy, Technical Measurements Center, Grand Junction, Colorado.

Mendenhall, W., and R.L. Scheaffer, 1973. Mathematical Statistics with Applications, Duxbury Press, North Scituate, Massachusetts.

Nelson, R., A., 1987. Measurement Uncertainties of Long Term $\mathrm{Rn}^{222}$ Averages at Environmental Levels Using Alpha Track Detectors, Health Physics, Vol 53, No. 5.

Pearson, M.D., 1989. Evaluation of the Performance Characteristics of Radon and Radon Daughter Concentration Measurement Devices Under Controlled Environmental Conditions, UNC/GJ-44(TMC), U.S. Department of Energy, Technical Measurements Center, Grand Junction, Colorado. 


\section{Appendix A}

Field Station Monitor Data 
Table A-1. Field Station Monitor Placement Dates and Reported Concentrations

\begin{tabular}{|c|c|c|c|c|c|c|c|c|}
\hline Station & $\begin{array}{c}\text { Date } \\
\text { In }\end{array}$ & $\begin{array}{l}\text { Date } \\
\text { Out }\end{array}$ & $\begin{array}{l}\text { Serial } \\
\text { Number }\end{array}$ & $\begin{array}{l}\text { Conc. } \\
\text { (pCi/L) }\end{array}$ & $\begin{array}{l}\text { Serial } \\
\text { Number }\end{array}$ & $\begin{array}{l}\text { Conc. } \\
\text { (pCi/L) }\end{array}$ & $\begin{array}{l}\text { Serial } \\
\text { Number }\end{array}$ & $\begin{array}{l}\text { Conc. } \\
\text { (pCl/L) }\end{array}$ \\
\hline 01 & $01 / 12 / 84$ & $01 / 15 / 85$ & 315325 & 3.1 & & & & \\
\hline 01 & $02 / 19 / 85$ & $02 / 28 / 86$ & 346005 & 2.4 & & & & \\
\hline 01 & $07 / 02 / 85$ & $07 / 07 / 86$ & 355938 & 2.7 & 355959 & 2.6 & 355960 & 2.3 \\
\hline 01 & $07 / 07 / 86$ & $07 / 01 / 87$ & 314331 & 3.2 & 314347 & 2.5 & & \\
\hline 01 & $07 / 01 / 87$ & $06 / 21 / 88$ & 502390 & 3.1 & 502397 & 3.1 & & \\
\hline 01 & $06 / 21 / 89$ & $07 / 14 / 89$ & 578729 & 2.4 & 518749 & 2.4 & & \\
\hline 02 & $01 / 12 / 84$ & $01 / 15 / 85$ & 315300 & 1.1 & 315311 & 0.9 & & \\
\hline 02 & 02/19/85 & 02/28/86 & 346006 & 0.7 & & & & \\
\hline 02 & 07/02/85 & $07 / 07 / 86$ & 355721 & 0.6 & 355722 & 0.5 & 355735 & 0.4 \\
\hline 02 & 07/07/86 & $07 / 01 / 87$ & 314334 & 0.8 & 314360 & 0.7 & & \\
\hline 02 & $07 / 01 / 87$ & $06 / 21 / 88$ & 502389 & 1.2 & 502399 & 1.0 & & \\
\hline 02 & $06 / 21 / 88$ & $07 / 14 / 89$ & 518659 & 1.3 & 518679 & 1.0 & & \\
\hline 03 & $03 / 03 / 85$ & $03 / 14 / 86$ & 346008 & 1.2 & $\cdot$ & & & \\
\hline 04 & $01 / 17 / 84$ & $01 / 17 / 85$ & 315337 & 1.1 & & & & \\
\hline 04 & $03 / 03 / 85$ & $03 / 14 / 86$ & 346021 & 0.7 & & & & \\
\hline 05 & $01 / 20 / 84$ & $01 / 23 / 85$ & 315338 & 1.8 & & & & \\
\hline 05 & $02 / 20 / 85$ & $02 / 27 / 86$ & 346002 & 2.1 & & & & \\
\hline 05 & $07 / 02 / 85$ & $07 / 01 / 86$ & 355801 & 1.5 & 355802 & 1.5 & 355803 & 1.5 \\
\hline 05 & $07 / 01 / 86$ & $07 / 13 / 87$ & 314441 & 1.8 & 314455 & 1.9 & & \\
\hline 05 & $07 / 13 / 87$ & $07 / 18 / 88$ & 502409 & 2.0 & 502423 & 1.6 & & \\
\hline 05 & $07 / 18 / 88$ & $06 / 28 / 89$ & 518709 & 1.8 & 518689 & 1.6 & & \\
\hline 06 & $01 / 20 / 84$ & $01 / 21 / 85$ & 315296 & 1.8 & 315348 & 2.1 & & \\
\hline 06 & $02 / 21 / 85$ & 03/03/86 & 346015 & 1.4 & 346020 & 1.5 & & \\
\hline 06 & $07 / 01 / 85$ & 07/01/86 & 355937 & 2.2 & 355941 & 2.0 & 355942 & 2.2 \\
\hline 06 & 07/01/86 & $07 / 01 / 87$ & 314431 & 1.7 & 314459 & 3.3 & & \\
\hline 06 & $07 / 01 / 87$ & $06 / 21 / 88$ & 502366 & 2.1 & 502388 & 2.3 & & \\
\hline 06 & $06 / 21 / 88$ & $06 / 28 / 89$ & 518647 & 1.4 & 518666 & 1.4 & & \\
\hline 07 & $01 / 26 / 84$ & $01 / 29 / 85$ & 315326 & 1.0 & & & & \\
\hline 07 & $03 / 13 / 85$ & $03 / 28 / 86$ & 346012 & 1.0 & & & & \\
\hline 07 & $07 / 08 / 85$ & $07 / 01 / 86$ & 355781 & 0.6 & 355792 & 0.8 & 355796 & 1.0 \\
\hline 07 & $07 / 01 / 86$ & $07 / 01 / 87$ & 314429 & 1.1 & 314456 & 1.5 & & \\
\hline 07 & $07 / 01 / 87$ & $06 / 30 / 88$ & 502410 & 1.3 & 502435 & 2.1 & & \\
\hline 07 & $06 / 30 / 88$ & $07 / 18 / 89$ & 518737 & 1.3 & 518758 & 1.1 & & \\
\hline 08 & $01 / 26 / 84$ & $01 / 29 / 85$ & 315327 & 1.2 & 315331 & 1.8 & & \\
\hline 08 & $03 / 13 / 85$ & $03 / 28 / 86$ & 346016 & 1.2 & & & & \\
\hline 08 & 07/08/85 & 07/01/86 & 355712 & 1.6 & 355748 & 1.3 & 355751 & 1.3 \\
\hline 08 & $07 / 01 / 86$ & $07 / 01 / 87$ & 314418 & 1.9 & 314442 & 2.2 & & \\
\hline
\end{tabular}


Table A-1. Field Station Monitor Placement Dates and Reported Concentrations

\begin{tabular}{|c|c|c|c|c|c|c|c|c|}
\hline Station & $\begin{array}{c}\text { Date } \\
\text { In }\end{array}$ & $\begin{array}{l}\text { Date } \\
\text { Out }\end{array}$ & $\begin{array}{c}\text { Serial } \\
\text { Number }\end{array}$ & $\begin{array}{l}\text { Conc. } \\
\text { (pCl/L) }\end{array}$ & $\begin{array}{c}\text { Serial } \\
\text { Number }\end{array}$ & $\begin{array}{l}\text { Conc. } \\
\text { (pCl/L) }\end{array}$ & $\begin{array}{c}\text { Serial } \\
\text { Number }\end{array}$ & $\begin{array}{l}\text { Conc. } \\
\text { (pCl/L) }\end{array}$ \\
\hline 08 & $07 / 01 / 87$ & $06 / 23 / 88$ & 502430 & 2.4 & 502433 & 2.4 & & \\
\hline 08 & $06 / 23 / 88$ & 07/18/89 & 518649 & 1.7 & 518669 & 1.6 & & \\
\hline 09 & $01 / 26 / 84$ & $01 / 30 / 85$ & 315316 & 2.5 & 315329 & 2.4 & & \\
\hline 09 & $02 / 20 / 85$ & $03 / 01 / 86$ & 346001 & 2.3 & 346003 & 2.0 & & \\
\hline 09 & 07/02/85 & $07 / 02 / 86$ & 355812 & 2.6 & 355825 & 2.2 & 355826 & 2.1 \\
\hline 09 & $07 / 02 / 86$ & 07/01/87 & 314421 & 2.3 & 314445 & 2.4 & & \\
\hline 09 & $07 / 01 / 87$ & 07/20/88 & 502392 & 2.6 & 502400 & 4.3 & & \\
\hline 09 & $07 / 20 / 88$ & $06 / 28 / 89$ & 518698 & 2.2 & 518718 & 2.3 & & \\
\hline 10 & $01 / 26 / 84$ & $01 / 29 / 85$ & 315314 & 1.5 & & & & \\
\hline 10 & $02 / 22 / 85$ & $02 / 28 / 86$ & 346004 & 1.4 & & & & \\
\hline 10 & $07 / 01 / 85$ & $06 / 27 / 86$ & 355836 & 1.5 & 355842 & 1.5 & 355843 & 2.1 \\
\hline 10 & $06 / 27 / 86$ & $07 / 01 / 87$ & 314439 & 1.0 & 314452 & 1.2 & & \\
\hline 10 & $07 / 01 / 87$ & $06 / 20 / 88$ & 502356 & 2.3 & 502376 & 1.4 & & \\
\hline 10 & $06 / 20 / 88$ & $06 / 20 / 89$ & 518635 & 1.5 & 518670 & 1.5 & & \\
\hline 11 & $01 / 26 / 84$ & $01 / 29 / 85$ & 315315 & 2.8 & & & & \\
\hline 11 & $02 / 22 / 85$ & $02 / 28 / 86$ & 346010 & 3.6 & & & & \\
\hline 11 & $07 / 01 / 85$ & $06 / 27 / 86$ & 355840 & 3.0 & 355841 & 3.2 & 355845 & 3.4 \\
\hline 11 & $06 / 27 / 86$ & $07 / 01 / 87$ & 314428 & 1.4 & 314466 & 2.1 & & \\
\hline 11 & $07 / 01 / 87$ & $06 / 20 / 88$ & 502365 & 3.1 & 502395 & 3.2 & & \\
\hline 11 & $06 / 20 / 88$ & $07 / 24 / 89$ & 518650 & 1.7 & 518690 & 1.8 & & \\
\hline 12 & $01 / 27 / 84$ & $01 / 29 / 85$ & 315309 & 2.4 & 315336 & 2.2 & & \\
\hline 12 & 03/13/85 & $03 / 26 / 86$ & 346011 & 2.0 & 346014 & 2.3 & & \\
\hline 12 & $07 / 03 / 85$ & $07 / 02 / 86$ & 355870 & 2.3 & 355871 & 2.3 & 355872 & 2.1 \\
\hline 12 & $07 / 02 / 86$ & $07 / 07 / 87$ & 314434 & 1.6 & 314460 & 1.8 & & \\
\hline 12 & $07 / 07 / 87$ & $07 / 04 / 88$ & 502354 & 2.0 & 502358 & 1.6 & & \\
\hline 12 & $07 / 04 / 88$ & $06 / 21 / 89$ & 518728 & 2.1 & 518748 & 2.1 & & \\
\hline 13 & $01 / 27 / 84$ & $01 / 29 / 85$ & 315324 & 0.5 & & & & \\
\hline 13 & $03 / 13 / 85$ & $03 / 26 / 86$ & 346018 & 0.3 & & & & \\
\hline 13 & $07 / 03 / 85$ & 07/02/86 & 355892 & 0.6 & 355893 & 0.6 & 355894 & 0.4 \\
\hline 13 & $07 / 02 / 86$ & $07 / 07 / 87$ & 314422 & 0.6 & 314446 & 0.4 & & \\
\hline 13 & $07 / 07 / 87$ & $07 / 04 / 88$ & 502363 & 0.6 & 502364 & 0.7 & & \\
\hline 13 & $07 / 04 / 88$ & $06 / 21 / 89$ & 518678 & 0.5 & 518688 & 0.5 & & \\
\hline 14 & $02 / 09 / 84$ & $02 / 08 / 85$ & 315305 & 1.0 & 315307 & 1.1 & & \\
\hline 14 & $02 / 27 / 85$ & 03/09/86 & 346019 & 0.7 & & & & \\
\hline 14 & $07 / 03 / 85$ & $07 / 10 / 86$ & 355865 & 0.9 & 355866 & 0.9 & 355867 & 1.0 \\
\hline 14 & $07 / 10 / 86$ & $07 / 08 / 87$ & 314346 & 0.8 & 314359 & 1.0 & & \\
\hline 14 & $07 / 08 / 87$ & 07/08/88 & 502420 & 1.2 & 502413 & 0.8 & & \\
\hline 14 & $07 / 07 / 88$ & $06 / 30 / 89$ & 518688 & 1.0 & 518708 & 1.2 & & \\
\hline
\end{tabular}


Table A-1. Field Station Monitor Placement Dates and Reported Concentrations

\begin{tabular}{|c|c|c|c|c|c|c|c|c|}
\hline Station & $\begin{array}{l}\text { Date } \\
\text { In }\end{array}$ & $\begin{array}{l}\text { Date } \\
\text { Out }\end{array}$ & $\begin{array}{l}\text { Serial } \\
\text { Number }\end{array}$ & $\begin{array}{l}\text { Conc. } \\
\text { (pCi/L) }\end{array}$ & $\begin{array}{c}\text { Serial } \\
\text { Number }\end{array}$ & $\begin{array}{l}\text { Conc. } \\
\text { (pCl/L) }\end{array}$ & $\begin{array}{l}\text { Serial } \\
\text { Number }\end{array}$ & $\begin{array}{l}\text { Conc. } \\
\text { (pCl/L) }\end{array}$ \\
\hline 15 & $02 / 09 / 84$ & $02 / 07 / 85$ & 315321 & 3.5 & 315340 & 3.8 & & . \\
\hline 16 & $02 / 10 / 84$ & 02/08/85 & 315303 & 0.9 & & & & \\
\hline 16 & $02 / 28 / 85$ & $02 / 28 / 86$ & 346007 & 0.8 & & & & \\
\hline 16 & 07/08/85 & $07 / 02 / 86$ & 355770 & 0.6 & 355771 & 0.5 & 355772 & 0.7 \\
\hline 16 & $07 / 02 / 86$ & 07/01/87 & 314433 & 0.9 & 314461 & 1.3 & & \\
\hline 16 & $07 / 01 / 87$ & $06 / 21 / 88$ & 502372 & 1.0 & 502381 & 1.5 & & \\
\hline 16 & $06 / 21 / 88$ & $06 / 20 / 89$ & 518716 & 1.1 & 518736 & 1.0 & & \\
\hline 17 & $02 / 29 / 84$ & $03 / 14 / 85$ & 315322 & 0.8 & & & & \\
\hline 17 & $03 / 14 / 85$ & $03 / 29 / 86$ & 346041 & 0.9 & & & & \\
\hline 17 & $07 / 01 / 85$ & 07/03/86 & 355945 & 0.9 & 355946 & 0.9 & 355947 & 1.0 \\
\hline 17 & $07 / 03 / 86$ & $06 / 17 / 87$ & 314325 & 0.8 & 314353 & 0.9 & & \\
\hline 17 & $06 / 17 / 87$ & $07 / 14 / 88$ & 502440 & d & 502441 & $d$ & & \\
\hline 17 & $07 / 14 / 88$ & $06 / 22 / 89$ & 518646 & 1.0 & 518696 & 1.1 & & \\
\hline 18 & $03 / 07 / 84$ & $03 / 21 / 85$ & 315301 & 1.3 & 315318 & 0.9 & & \\
\hline 18 & $03 / 21 / 85$ & 04/01/86 & 346043 & 1.2 & 346045 & 1.0 & & \\
\hline 18 & $07 / 01 / 85$ & 07/01/86 & 355931 & 1.3 & 355932 & 1.4 & 355934 & 1.3 \\
\hline 18 & 07/01/86 & $06 / 30 / 87$ & 314420 & d & 314443 & 1.0 & & \\
\hline 18 & $06 / 30 / 87$ & $06 / 27 / 88$ & 502352 & 1.7 & 502404 & d & & \\
\hline 18 & $06 / 27 / 88$ & $06 / 20 / 89$ & 518735 & d & 518756 & d & & \\
\hline 19 & 03/01/84 & 03/08/85 & 315299 & 1.9 & & & & \\
\hline 19 & $03 / 12 / 85$ & $04 / 02 / 86$ & 346009 & 1.6 & & & & \\
\hline 19 & $07 / 02 / 85$ & $07 / 02 / 86$ & 355813 & 1.9 & 355814 & 1.6 & 355815 & 1.5 \\
\hline 19 & 07/02/86 & $07 / 13 / 87$ & 314471 & 1.7 & 314475 & $d$ & & \\
\hline 19 & $07 / 13 / 87$ & $06 / 30 / 88$ & 502398 & 2.2 & 599942 & 1.9 & & \\
\hline 19 & $06 / 30 / 88$ & $06 / 22 / 89$ & 518735 & 1.5 & 518727 & 1.3 & & \\
\hline 20 & 03/01/84 & $03 / 08 / 85$ & 315317 & 3.0 & 315333 & 3.5 & & \\
\hline 20 & $03 / 12 / 85$ & $04 / 02 / 86$ & 346013 & 2.8 & & & & \\
\hline 20 & $07 / 02 / 85$ & $07 / 02 / 86$ & 355818 & 3.1 & 355827 & 3.3 & 355828 & 2.5 \\
\hline 20 & $07 / 02 / 86$ & $07 / 13 / 87$ & 314474 & 2.6 & 314482 & 1 & 0.3 & \\
\hline 20 & $07 / 13 / 87$ & $06 / 30 / 88$ & 599944 & 2.2 & 599953 & 2.5 & & \\
\hline 20 & $06 / 30 / 88$ & $06 / 22 / 89$ & 518727 & 2.4 & 518747 & 2.8 & & \\
\hline 21 & 03/07/84 & $03 / 21 / 85$ & 315302 & 7.7 & 315332 & 7.7 & & \\
\hline 21 & $03 / 21 / 85$ & $04 / 01 / 86$ & 346042 & 7.0 & 346046 & 7.7 & & \\
\hline 21 & $07 / 01 / 85$ & $07 / 02 / 86$ & 355953 & 7.5 & 355954 & 7.8 & 355955 & 7.7 \\
\hline 21 & 07/02/86 & $06 / 30 / 87$ & 314469 & d & 314480 & d & & \\
\hline 21 & $06 / 30 / 87$ & $06 / 27 / 88$ & 502401 & 5.0 & 502415 & 5.1 & & \\
\hline 21 & $06 / 27 / 88$ & $06 / 20 / 89$ & 518726 & 6.5 & 518745 & 6.5 & & \\
\hline
\end{tabular}


Table A-1. Field Station Monitor Placement Dates and Reported Concentrations

\begin{tabular}{|c|c|c|c|c|c|c|c|c|}
\hline Station & $\begin{array}{l}\text { Date } \\
\text { In }\end{array}$ & $\begin{array}{l}\text { Date } \\
\text { Out }\end{array}$ & $\begin{array}{c}\text { Serial } \\
\text { Number }\end{array}$ & $\begin{array}{l}\text { Conc. } \\
\text { (pCi/L) }\end{array}$ & $\begin{array}{c}\text { Serlal } \\
\text { Number }\end{array}$ & $\begin{array}{l}\text { Conc. } \\
\text { (pCl/L) }\end{array}$ & $\begin{array}{c}\text { Serlal } \\
\text { Number }\end{array}$ & $\begin{array}{l}\text { Conc. } \\
\text { (pCl/L) }\end{array}$ \\
\hline 22 & $03 / 07 / 84$ & $03 / 21 / 85$ & 315293 & 1.8 & & & & \\
\hline 22 & $03 / 21 / 85$ & $04 / 01 / 86$ & 346040 & 0.8 & & & & \\
\hline 22 & $07 / 01 / 85$ & $07 / 02 / 86$ & 355837 & 0.9 & 355849 & 1.3 & 355850 & 1.2 \\
\hline 22 & $07 / 02 / 86$ & $06 / 30 / 87$ & 314470 & d & 314481 & $d$ & & \\
\hline 22 & $06 / 30 / 87$ & $06 / 27 / 88$ & 502396 & d & 502402 & d & & \\
\hline 22 & $06 / 27 / 88$ & $06 / 20 / 89$ & 518656 & d & 518676 & d & & \\
\hline 23 & 03/19/84 & $03 / 25 / 85$ & 315304 & 2.0 & & & & \\
\hline 23 & $03 / 25 / 85$ & $04 / 01 / 86$ & 346038 & 2.2 & & & & \\
\hline 23 & $07 / 01 / 85$ & $07 / 01 / 86$ & 355702 & 1.5 & 355703 & 1.6 & 355704 & 2.0 \\
\hline 23 & 07/01/86 & $06 / 30 / 87$ & 314476 & 2.3 & 314485 & 2.2 & & \\
\hline 23 & $06 / 30 / 87$ & $06 / 27 / 88$ & 502360 & 2.0 & 502417 & 2.3 & & \\
\hline 23 & $06 / 27 / 88$ & $06 / 20 / 89$ & 578710 & 1.6 & 578730 & 1.4 & & \\
\hline 24 & $03 / 19 / 84$ & $03 / 25 / 85$ & 315297 & 2.1 & 315319 & 2.1 & & \\
\hline 24 & $03 / 25 / 85$ & $04 / 01 / 86$ & 346030 & 1.7 & 346044 & 1.6 & & \\
\hline 24 & $07 / 01 / 85$ & $07 / 01 / 86$ & 355707 & 1.3 & 355708 & 1.0 & 355709 & 1.8 \\
\hline 24 & $07 / 01 / 86$ & $06 / 30 / 87$ & 314477 & 1.4 & 314484 & 1.7 & & \\
\hline 24 & $06 / 30 / 87$ & $06 / 27 / 88$ & 502378 & d & 502384 & $d$ & & \\
\hline 24 & $06 / 27 / 88$ & $06 / 20 / 89$ & 518637 & d & 518750 & d & & \\
\hline 25 & 03/23/84 & 03/28/85 & 315335 & 2.0 & & & & \\
\hline 25 & $03 / 28 / 85$ & $03 / 27 / 86$ & 346034 & 0.9 & & & & \\
\hline 25 & $07 / 03 / 85$ & 07/03/86 & 355913 & 0.8 & 355914 & 0.9 & 355915 & 0.9 \\
\hline 25 & $07 / 03 / 86$ & $07 / 09 / 87$ & 314319 & 0.9 & 314332 & 1.0 & & \\
\hline 25 & $07 / 09 / 87$ & $06 / 21 / 88$ & 502421 & 1.2 & 502443 & 1.3 & & \\
\hline 26 & $03 / 23 / 84$ & $04 / 01 / 85$ & 330434 & 0.8 & 330436 & 1.1 & & \\
\hline 26 & $04 / 01 / 85$ & $03 / 31 / 86$ & 346039 & 0.8 & & & & \\
\hline 26 & $07 / 03 / 85$ & $07 / 03 / 86$ & 355747 & 0.6 & 355927 & 0.9 & 355928 & 0.8 \\
\hline 26 & $07 / 03 / 86$ & $07 / 09 / 87$ & 314320 & 1.4 & 314348 & 1.5 & & \\
\hline 26 & $07 / 09 / 87$ & $06 / 22 / 88$ & 599956 & 0.9 & 599958 & 0.9 & & \\
\hline 26 & $06 / 22 / 88$ & $06 / 21 / 89$ & 518645 & 0.8 & 518664 & 1.0 & & \\
\hline 27 & $03 / 22 / 84$ & $03 / 25 / 85$ & 330438 & 0.9 & 330439 & 1.0 & & \\
\hline 27 & $03 / 25 / 85$ & $03 / 27 / 86$ & 346029 & 1.2 & & & & \\
\hline 27 & $07 / 01 / 85$ & $07 / 06 / 86$ & 355724 & 0.8 & 355736 & 0.8 & 355939 & 1.3 \\
\hline 27 & $07 / 06 / 86$ & $07 / 06 / 87$ & 314423 & 1.4 & 314447 & 1.3 & & \\
\hline 27 & $07 / 06 / 87$ & $06 / 21 / 88$ & 502370 & 1.8 & 502380 & 1.6 & & \\
\hline 27 & $06 / 21 / 88$ & $07 / 13 / 89$ & 518755 & 1.5 & 518744 & 1.6 & & \\
\hline 28 & $03 / 23 / 84$ & $04 / 01 / 85$ & 330437 & 1.0 & & & & \\
\hline 28 & $04 / 01 / 85$ & $03 / 31 / 86$ & 346022 & 0.8 & & & & \\
\hline 28 & $07 / 03 / 85$ & $07 / 03 / 86$ & 355921 & 1.0 & 355922 & 1.2 & 355923 & 1.0 \\
\hline
\end{tabular}


Table A-1. Field Station Monitor Placement Dates and Reported Concentrations

\begin{tabular}{|c|c|c|c|c|c|c|c|c|}
\hline Station & $\begin{array}{l}\text { Date } \\
\text { In }\end{array}$ & $\begin{array}{l}\text { Date } \\
\text { Out }\end{array}$ & $\begin{array}{c}\text { Serial } \\
\text { Number }\end{array}$ & $\begin{array}{l}\text { Conc. } \\
\text { (pCi/L) }\end{array}$ & $\begin{array}{c}\text { Serial } \\
\text { Number }\end{array}$ & $\begin{array}{l}\text { Conc. } \\
\text { (pCl/L) }\end{array}$ & $\begin{array}{c}\text { Serial } \\
\text { Number }\end{array}$ & $\begin{array}{l}\text { Conc. } \\
\text { (pCl/L) }\end{array}$ \\
\hline 28 & 07/03/86 & 07/09/87 & 314335 & 1.7 & 314362 & 1.8 & & \\
\hline 28 & $07 / 09 / 87$ & $06 / 22 / 88$ & 599957 & 1.3 & 599959 & 1.1 & & \\
\hline 28 & $06 / 22 / 88$ & $07 / 21 / 89$ & 518686 & 1.1 & 518706 & 1.3 & & \\
\hline 29 & $03 / 23 / 84$ & $04 / 03 / 85$ & 330448 & 1.7 & & & & \\
\hline 29 & $04 / 03 / 85$ & $03 / 31 / 86$ & 346025 & 1.5 & & & & \\
\hline 29 & $07 / 09 / 85$ & $07 / 03 / 86$ & 355764 & 1.4 & 355768 & 1.6 & 355780 & 1.1 \\
\hline 29 & $07 / 03 / 86$ & $07 / 08 / 87$ & 314323 & 1.6 & 314350 & 1.8 & & \\
\hline 29 & $07 / 13 / 87$ & $06 / 27 / 88$ & 599945 & 1.1 & 599950 & 1.2 & & \\
\hline 29 & $06 / 27 / 88$ & $06 / 28 / 89$ & 518644 & d & 518663 & d & & \\
\hline 30 & $03 / 23 / 84$ & $04 / 03 / 85$ & 330426 & 2.2 & 330428 & 2.4 & & \\
\hline 30 & $04 / 03 / 85$ & $03 / 31 / 86$ & 346027 & 2.0 & & & & \\
\hline 30 & 07/09/85 & $07 / 03 / 86$ & 355760 & 1.5 & 355761 & 2.0 & 355762 & 1.7 \\
\hline 30 & 07/03/86 & $07 / 13 / 87$ & 314338 & 2.2 & 314363 & 2.4 & & \\
\hline 30 & $07 / 14 / 87$ & $06 / 27 / 88$ & 599940 & 2.1 & 599948 & 1.9 & & \\
\hline 30 & $07 / 27 / 88$ & $06 / 28 / 89$ & 518685 & 1.9 & 518705 & 2.0 & & \\
\hline 31 & $03 / 23 / 84$ & $03 / 27 / 85$ & 330451 & 0.8 & & & & \\
\hline 31 & $03 / 27 / 85$ & $05 / 02 / 86$ & 346031 & 1.1 & & & & \\
\hline 31 & $07 / 09 / 85$ & $07 / 03 / 86$ & 355752 & 1.0 & 355753 & 1.0 & 355758 & 1.4 \\
\hline 31 & $07 / 03 / 86$ & $07 / 09 / 87$ & 314339 & 1.4 & 314364 & 1.2 & & \\
\hline 31 & $07 / 09 / 87$ & $07 / 07 / 88$ & 502438 & 1.5 & 502442 & 1.6 & & \\
\hline 31 & $07 / 07 / 88$ & $06 / 28 / 89$ & 518684 & 1.4 & 518704 & 1.3 & & \\
\hline 32 & $03 / 23 / 84$ & 03/27/85 & 330449 & 2.1 & 330450 & 1.8 & & \\
\hline 32 & $03 / 27 / 85$ & $05 / 02 / 86$ & 346028 & 2.7 & & & & \\
\hline 32 & $07 / 09 / 85$ & $07 / 03 / 86$ & 355862 & 2.4 & 355863 & 2.6 & 355904 & 2.7 \\
\hline 32 & $07 / 03 / 86$ & 07/09/87 & 314324 & 2.7 & 314352 & 2.7 & & \\
\hline 32 & $07 / 09 / 87$ & $07 / 07 / 88$ & 502419 & 3.4 & 502432 & 3.5 & & \\
\hline 32 & $07 / 07 / 88$ & $06 / 28 / 89$ & 518725 & 2.4 & 518743 & 2.9 & & \\
\hline 33 & 03/30/84 & $04 / 09 / 85$ & 330445 & 0.9 & 330446 & 0.8 & & \\
\hline 33 & $04 / 09 / 85$ & $05 / 02 / 86$ & 346035 & 1.0 & & & & \\
\hline 33 & 07/02/85 & $07 / 02 / 86$ & 355807 & 0.9 & 355808 & 0.7 & 355809 & 1.5 \\
\hline 33 & $07 / 02 / 86$ & $06 / 30 / 87$ & 314435 & 1.5 & 314462 & 2.0 & & \\
\hline 33 & $06 / 30 / 87$ & $12 / 01 / 88$ & 502375 & 1.7 & 502385 & 3.0 & & \\
\hline 33 & $06 / 06 / 88$ & $06 / 28 / 89$ & 518759 & 1.2 & 518739 & 1.7 & & \\
\hline 34 & $03 / 26 / 84$ & $04 / 03 / 85$ & 330430 & 1.1 & & & & \\
\hline 34 & $04 / 03 / 85$ & $05 / 01 / 86$ & 346032 & 1.1 & & & & \\
\hline 35 & $03 / 26 / 84$ & $04 / 03 / 85$ & 330431 & 1.1 & & & & \\
\hline 35 & 04/03/85 & $05 / 01 / 86$ & 346033 & 0.6 & & & & \\
\hline
\end{tabular}


Table A-1. Field Station Monitor Placement Dates and Reported Concentrations

\begin{tabular}{|c|c|c|c|c|c|c|c|c|}
\hline Station & $\begin{array}{l}\text { Date } \\
\text { In }\end{array}$ & $\begin{array}{l}\text { Date } \\
\text { Out }\end{array}$ & $\begin{array}{l}\text { Serial } \\
\text { Number }\end{array}$ & $\begin{array}{l}\text { Conc. } \\
\text { (pCl/L) }\end{array}$ & $\begin{array}{l}\text { Serial } \\
\text { Number }\end{array}$ & $\begin{array}{l}\text { Conc. } \\
\text { (pCi/L) }\end{array}$ & $\begin{array}{c}\text { Serial } \\
\text { Number }\end{array}$ & $\begin{array}{l}\text { Conc. } \\
\text { (pCi/L) }\end{array}$ \\
\hline 36 & $03 / 30 / 84$ & $04 / 18 / 85$ & 330444 & 5.1 & 330458 & 5.5 & & \\
\hline 36 & $04 / 18 / 85$ & 05/01/86 & 346053 & 5.4 & 346054 & 5.3 & & \\
\hline 36 & $07 / 02 / 85$ & $07 / 08 / 86$ & 355701 & 4.5 & 355743 & 4.1 & 355744 & 4.4 \\
\hline 36 & 07/08/86 & $06 / 09 / 87$ & 314333 & 4.6 & 314345 & 4.8 & & \\
\hline 36 & $06 / 09 / 87$ & $07 / 28 / 88$ & 502426 & 5.1 & 502450 & 4.5 & & \\
\hline 36 & $07 / 28 / 88$ & $06 / 30 / 89$ & 518683 & 3.6 & 518702 & 4.6 & & \\
\hline 37 & $03 / 30 / 84$ & $04 / 18 / 85$ & 330457 & 2.0 & & & & \\
\hline 37 & $04 / 18 / 85$ & $05 / 01 / 86$ & 346055 & 1.3 & & & & \\
\hline 37 & $07 / 02 / 85$ & $07 / 08 / 86$ & 355738 & 1.4 & 355739 & 1.2 & 355740 & 1.8 \\
\hline 37 & 07/08/86 & $06 / 09 / 87$ & 314341 & 2.4 & 314358 & 2.5 & & \\
\hline 37 & $06 / 09 / 87$ & 07/28/88 & 502407 & 2.2 & 502427 & 2.0 & & \\
\hline 37 & $07 / 28 / 88$ & $06 / 30 / 89$ & 518724 & 1.5 & 518742 & 1.8 & & \\
\hline 38 & $04 / 19 / 84$ & $04 / 15 / 85$ & 330407 & 3.7 & 330456 & 3.2 & & \\
\hline 38 & $04 / 15 / 85$ & 05/07/86 & 346023 & 2.9 & & & & \\
\hline 38 & $07 / 04 / 85$ & 07/02/86 & 355887 & 3.2 & 355888 & 3.9 & 355889 & 3.6 \\
\hline 38 & $07 / 02 / 86$ & $07 / 13 / 87$ & 314328 & 3.7 & 314468 & 4.3 & & \\
\hline 38 & $07 / 13 / 87$ & $06 / 21 / 88$ & 599943 & 4.9 & 599949 & 4.8 & & \\
\hline 38 & $06 / 21 / 88$ & $06 / 30 / 89$ & 518723 & 4.0 & 518741 & 3.3 & & \\
\hline 39 & $04 / 19 / 84$ & $04 / 15 / 85$ & 330454 & 7.1 & 330455 & 8.0 & & \\
\hline 39 & $04 / 15 / 85$ & $05 / 07 / 86$ & 346024 & 7.8 & 346026 & 6.8 & & \\
\hline 39 & $07 / 04 / 85$ & 07/02/86 & 355882 & 8.0 & 355883 & 8.0 & 355884 & 7.3 \\
\hline 39 & $07 / 02 / 86$ & $07 / 13 / 87$ & 314326 & 10.4 & 314479 & 8.7 & & \\
\hline 39 & $07 / 13 / 87$ & $06 / 21 / 88$ & 599941 & 9.9 & 599955 & 10.9 & & \\
\hline 39 & $06 / 21 / 88$ & $06 / 30 / 89$ & 518643 & 7.8 & 518662 & 7.0 & & \\
\hline 42 & $04 / 19 / 84$ & $05 / 08 / 85$ & 330432 & 10.6 & 330442 & 10.1 & & \\
\hline 42 & 05/08/85 & 05/01/86 & 346060 & 7.7 & 346069 & 7.3 & & \\
\hline 42 & $07 / 01 / 85$ & $07 / 01 / 86$ & 355819 & 7.4 & 355820 & 7.8 & 355821 & 8.4 \\
\hline 42 & $07 / 01 / 86$ & 07/08/87 & 314430 & 6.7 & 314457 & 8.1 & & \\
\hline 42 & $07 / 08 / 87$ & $06 / 27 / 88$ & 502414 & 12.1 & 502446 & 8.5 & & \\
\hline 42 & $06 / 27 / 88$ & $06 / 20 / 89$ & 518681 & 5.3 & 518701 & 5.1 & & \\
\hline 43 & $04 / 19 / 84$ & $04 / 29 / 85$ & 330427 & 6.7 & & & & \\
\hline 43 & $04 / 29 / 85$ & $05 / 01 / 86$ & 346052 & 7.1 & & & & \\
\hline 43 & $07 / 01 / 85$ & $07 / 01 / 86$ & 355715 & 5.8 & 355731 & 5.9 & 355732 & 4.6 \\
\hline 43 & $07 / 01 / 86$ & $07 / 08 / 87$ & 314440 & 3.6 & 314454 & 2.7 & & \\
\hline 43 & $07 / 08 / 87$ & $07 / 14 / 88$ & 502439 & 2.9 & 502449 & 3.0 & & \\
\hline 43 & $07 / 14 / 88$ & $06 / 28 / 08$ & 518733 & 2.6 & 518754 & 3.1 & & \\
\hline 44 & $04 / 19 / 84$ & $04 / 29 / 85$ & 330429 & 2.6 & 330459 & 2.2 & & \\
\hline 44 & $04 / 29 / 85$ & $05 / 01 / 86$ & 346059 & 1.9 & & & & \\
\hline
\end{tabular}


Table A-1. Field Station Monitor Placement Dates and Reported Concentrations

\begin{tabular}{|c|c|c|c|c|c|c|c|c|}
\hline Station & $\begin{array}{c}\text { Date } \\
\text { In }\end{array}$ & $\begin{array}{l}\text { Date } \\
\text { Out }\end{array}$ & $\begin{array}{c}\text { Serial } \\
\text { Number }\end{array}$ & $\begin{array}{l}\text { Conc. } \\
\text { (pCi/L) }\end{array}$ & $\begin{array}{l}\text { Serial } \\
\text { Number }\end{array}$ & $\begin{array}{l}\text { Conc. } \\
\text { (pCl/L) }\end{array}$ & $\begin{array}{l}\text { Serial } \\
\text { Number }\end{array}$ & $\begin{array}{l}\text { Conc. } \\
\text { (pCl/L) }\end{array}$ \\
\hline 44 & $07 / 01 / 85$ & $07 / 01 / 86$ & 355714 & 1.6 & 355716 & 1.6 & 355717 & 1.7 \\
\hline 44 & $07 / 01 / 86$ & $07 / 08 / 87$ & 314417 & 0.8 & 314453 & 1.0 & & \\
\hline 44 & $07 / 08 / 87$ & $07 / 14 / 88$ & 502412 & 1.9 & 502422 & 1.1 & & \\
\hline 44 & $07 / 14 / 88$ & $06 / 28 / 89$ & 518642 & 1.2 & 518661 & 1.3 & & \\
\hline 45 & $07 / 02 / 85$ & 07/03/86 & 355726 & 0.6 & 355727 & 1.0 & 355728 & 1.0 \\
\hline 45 & $07 / 03 / 86$ & $07 / 08 / 87$ & 314424 & 2.4 & 314448 & 1.6 & & \\
\hline 45 & $07 / 08 / 87$ & $06 / 29 / 88$ & 502367 & 1.4 & 502383 & 2.6 & & \\
\hline 45 & $06 / 29 / 88$ & $06 / 21 / 89$ & 518694 & 1.5 & 518714 & 1.4 & & \\
\hline 46 & $07 / 09 / 85$ & $07 / 14 / 86$ & 355785 & 0.9 & 355786 & 1.7 & 355787 & 0.9 \\
\hline 46 & $07 / 14 / 86$ & 07/09/87 & 314329 & 1.0 & 314355 & 1.3 & & \\
\hline 46 & $07 / 09 / 87$ & $06 / 27 / 88$ & 502424 & 1.1 & 502425 & 1.1 & & \\
\hline 47 & $07 / 09 / 85$ & $07 / 14 / 86$ & 355759 & 1.6 & 355775 & 1.6 & 355776 & 1.6 \\
\hline 47 & $07 / 14 / 86$ & $07 / 09 / 87$ & 314344 & 1.8 & 314357 & 1.8 & & \\
\hline 47 & $07 / 09 / 87$ & $06 / 27 / 88$ & 502406 & 1.9 & 502437 & 2.0 & & \\
\hline 48 & $07 / 09 / 85$ & $07 / 02 / 86$ & 355755 & 4.4 & 355756 & 4.9 & 355765 & 6.7 \\
\hline 48 & $07 / 09 / 87$ & $06 / 21 / 88$ & 502362 & 2.8 & 599952 & 3.1 & & \\
\hline 48 & $06 / 21 / 88$ & $06 / 30 / 89$ & 518693 & 2.8 & 518713 & 3.0 & & \\
\hline 49 & $07 / 11 / 85$ & $07 / 03 / 86$ & 355767 & 2.9 & 355779 & 3.3 & 355782 & 3.1 \\
\hline 49 & 07/03/86 & $06 / 30 / 87$ & 314436 & 2.9 & 314464 & 3.2 & & \\
\hline 49 & $06 / 30 / 87$ & $06 / 30 / 88$ & 502369 & 1.8 & 502373 & 1.6 & & \\
\hline 49 & $06 / 30 / 88$ & $06 / 30 / 89$ & 518639 & 1.7 & 518752 & 1.8 & & \\
\hline 50 & $07 / 11 / 85$ & $07 / 03 / 86$ & 355754 & 5.9 & 355757 & 9.5 & 355790 & 8.9 \\
\hline 50 & 07/03/86 & $06 / 30 / 87$ & 314426 & 8.1 & 314451 & 6.5 & & \\
\hline 50 & $06 / 30 / 87$ & $06 / 30 / 88$ & 502353 & 3.8 & 502357 & 4.2 & & \\
\hline 50 & $06 / 30 / 88$ & $06 / 30 / 89$ & 518653 & 3.3 & 518672 & 3.3 & & \\
\hline 51 & $07 / 03 / 85$ & $07 / 01 / 86$ & 355876 & 1.8 & 355877 & 1.7 & 355878 & 1.9 \\
\hline 51 & $07 / 01 / 86$ & $07 / 06 / 87$ & 314473 & 1.8 & 314486 & 3.1 & & \\
\hline 51 & $07 / 06 / 87$ & $07 / 19 / 88$ & 502416 & 1.9 & 502444 & 1.7 & & \\
\hline 51 & $07 / 18 / 88$ & $06 / 22 / 89$ & 518711 & 1.9 & 518737 & 1.6 & & \\
\hline 52 & $07 / 05 / 85$ & $07 / 08 / 86$ & 355857 & 3.2 & 355858 & 3.2 & 355859 & 3.1 \\
\hline 52 & $07 / 08 / 86$ & $07 / 01 / 87$ & 314438 & 3.5 & 314465 & 4.4 & & \\
\hline 52 & $07 / 01 / 87$ & $06 / 23 / 88$ & 502355 & 3.1 & 502374 & 4.1 & & \\
\hline 52 & $06 / 23 / 88$ & 06/30/89 & 518671 & 2.6 & 518692 & 2.4 & & \\
\hline 53 & $07 / 01 / 85$ & $07 / 03 / 86$ & 355831 & 2.7 & 355832 & 3.0 & 355833 & 2.4 \\
\hline 53 & $07 / 03 / 86$ & $06 / 30 / 87$ & 314317 & 2.8 & 314361 & 4.1 & & \\
\hline 53 & $06 / 30 / 87$ & $06 / 28 / 88$ & 502382 & 3.7 & 502434 & 6.0 & & \\
\hline
\end{tabular}


Table A-1. Field Station Monitor Placement Dates and Reported Concentrations

\begin{tabular}{|c|c|c|c|c|c|c|c|c|}
\hline Station & $\begin{array}{l}\text { Date } \\
\text { In }\end{array}$ & $\begin{array}{l}\text { Date } \\
\text { Out }\end{array}$ & $\begin{array}{c}\text { Serial } \\
\text { Number }\end{array}$ & $\begin{array}{l}\text { Conc. } \\
\text { (pCi/L) }\end{array}$ & $\begin{array}{c}\text { Serial } \\
\text { Number }\end{array}$ & $\begin{array}{l}\text { Conc. } \\
\text { (pCl/L) }\end{array}$ & $\begin{array}{l}\text { Serial } \\
\text { Number }\end{array}$ & $\begin{array}{l}\text { Conc. } \\
\text { (pCI/L) }\end{array}$ \\
\hline 53 & $06 / 28 / 88$ & $06 / 20 / 89$ & 518651 & 2.7 & 518638 & 3.0 & & \\
\hline 54 & $07 / 03 / 85$ & $07 / 03 / 86$ & 355902 & 0.7 & 355903 & 0.8 & 355906 & 0.7 \\
\hline 54 & 07/03/86 & $07 / 06 / 87$ & 314321 & 0.6 & 314349 & 0.7 & & \\
\hline 54 & $07 / 06 / 87$ & $06 / 22 / 88$ & 502403 & 1.0 & 502418 & 1.0 & & \\
\hline 54 & $06 / 22 / 88$ & $06 / 21 / 89$ & 518721 & 0.6 & 518740 & 0.5 & & \\
\hline 55 & $07 / 03 / 85$ & $07 / 03 / 86$ & 355909 & 3.3 & 355910 & 4.4 & 355918 & 3.5 \\
\hline 55 & $07 / 03 / 86$ & $07 / 06 / 87$ & 314322 & 3.6 & 314337 & 3.6 & & \\
\hline 55 & $07 / 06 / 87$ & $06 / 22 / 88$ & 502436 & 3.7 & 502447 & 4.0 & & \\
\hline 55 & $06 / 22 / 88$ & $06 / 21 / 89$ & 518680 & 2.8 & 518700 & 2.5 & & \\
\hline 56 & $07 / 03 / 85$ & $07 / 02 / 86$ & 355851 & 0.8 & 355852 & 1.0 & 355853 & 0.9 \\
\hline 56 & $07 / 02 / 86$ & $07 / 01 / 87$ & 314427 & 0.8 & 314449 & 0.9 & & \\
\hline 56 & $07 / 01 / 87$ & $06 / 22 / 88$ & 502379 & 1.4 & 502394 & 1.5 & & \\
\hline 56 & $06 / 22 / 88$ & $07 / 26 / 89$ & 518640 & 1.0 & 518660 & 0.9 & & \\
\hline 57 & $07 / 05 / 85$ & $07 / 03 / 86$ & 355856 & 10.7 & 355873 & 14.3 & 355900 & 11.7 \\
\hline 58 & 07/23/88 & $07 / 13 / 89$ & 518695 & 7.1 & 518695 & 6.7 & & \\
\hline 59 & 07/23/88 & $07 / 13 / 89$ & 518699 & 1.3 & 578719 & 1.4 & & \\
\hline
\end{tabular}




\section{Appendix B}

\section{Control Monitor Data}




\section{.}


Table B-1. Control and Background Data for Annual Average Radon Study; Control Set 1, 1984-1985 Data, Batch 18

\begin{tabular}{|c|c|c|c|c|c|}
\hline $\begin{array}{l}\text { Serial } \\
\text { Number }\end{array}$ & $\begin{array}{c}\text { Reported } \\
\text { Redon } \\
\text { (pCl/L) }\end{array}$ & $\begin{array}{c}\text { Track } \\
\text { Density } \\
(\text { trk/mm²) }\end{array}$ & $\begin{array}{l}\text { Reported } \\
\text { TIme } \\
\text { (d) }\end{array}$ & $\begin{array}{l}\text { Calculated } \\
\text { Exposure } \\
\text { (pCl-d/L) }\end{array}$ & $\begin{array}{c}\text { Actual } \\
\text { Exposure } \\
\text { (pCl-d/L) }\end{array}$ \\
\hline \multicolumn{6}{|c|}{ Background Monitors } \\
\hline 323481 & 0.28 & 0.5 & 90 & 25.2 & 0.0 \\
\hline 316219 & 0.46 & 0.8 & 90 & 41.4 & 0.0 \\
\hline 323468 & 0.55 & 0.9 & 90 & 49.5 & 0.0 \\
\hline 316187 & 1.09 & 1.9 & 90 & 98.1 & 0.0 \\
\hline 346075 & 1.13 & 0.2 & 10 & 11.3 & 0.0 \\
\hline 346036 & 2.49 & 0.5 & 10 & 24.9 & 0.0 \\
\hline 346017 & 2.49 & 0.5 & 10 & 24.9 & 0.0 \\
\hline \multicolumn{6}{|c|}{ Exposed Monitors } \\
\hline 316189 & 1.58 & 2.7 & 90 & 142.2 & 118.1 \\
\hline 323469 & 1.64 & 2.8 & 90 & 147.6 & 118.1 \\
\hline 323471 & 2.00 & 3.4 & 90 & 180.0 & 118.1 \\
\hline 316191 & 2.06 & 3.5 & 90 & 185.4 & 118.1 \\
\hline 346050 & 13.93 & 2.6 & 10 & 139.3 & 118.1 \\
\hline 346048 & 15.84 & 3.0 & 10 & 158.4 & 118.1 \\
\hline 316203 & 3.73 & 6.4 & 90 & 335.7 & 273.9 \\
\hline 316193 & 3.76 & 6.4 & 90 & 338.4 & 273.9 \\
\hline 323474 & 4.51 & 7.7 & 90 & 405.9 & 273.9 \\
\hline 323473 & 5.12 & 8.8 & 90 & 460.8 & 273.9 \\
\hline 346056 & 33.00 & 6.3 & 10 & 330.0 & 273.9 \\
\hline 346051 & 36.27 & 6.9 & 10 & 362.7 & 273.9 \\
\hline 323483 & 4.27 & 7.3 & 90 & 384.3 & 379.4 \\
\hline 316217 & 4.30 & 7.4 & 90 & 387.0 & 379.4 \\
\hline 316207 & 4.94 & 8.4 & 90 & 444.6 & 379.4 \\
\hline 323475 & 5.06 & 8.7 & 90 & 455.4 & 379.4 \\
\hline 346064 & 33.81 & 6.4 & 10 & 338.1 & 379.4 \\
\hline 346063 & 35.18 & 6.7 & 10 & 351.8 & 379.4 \\
\hline
\end{tabular}


Table B-2. Control and Background Data for Annual Average Radon Study; Control Set 2, 1985-1986 Data, Batch 18

\begin{tabular}{|c|c|c|c|c|c|}
\hline $\begin{array}{l}\text { Serial } \\
\text { Number }\end{array}$ & $\begin{array}{c}\text { Reported } \\
\text { Radon } \\
\text { (pCI/L) }\end{array}$ & $\begin{array}{c}\text { Track } \\
\text { Density } \\
\text { (trk/mm²) }\end{array}$ & $\begin{array}{l}\text { Reported } \\
\text { Time } \\
\text { (d) }\end{array}$ & $\begin{array}{l}\text { Calculated } \\
\text { Exposure } \\
\text { (pCl-d/L) }\end{array}$ & $\begin{array}{c}\text { Actual } \\
\text { Exposure } \\
\text { (pCl-d/L) }\end{array}$ \\
\hline \multicolumn{6}{|c|}{ Background Monitors } \\
\hline 346065 & 0.01 & 0.1 & 365 & 3.7 & 0.0 \\
\hline 346061 & 0.04 & 0.3 & 365 & 14.6 & 0.0 \\
\hline 346073 & 0.08 & 0.6 & 365 & 29.2 & 0.0 \\
\hline 346074 & 0.18 & 1.2 & 365 & 65.7 & 0.0 \\
\hline \multicolumn{6}{|c|}{ Exposed Monitors } \\
\hline 346062 & 2.62 & 18.2 & 365 & 956.3 & 1077.1 \\
\hline 346049 & 2.99 & 20.7 & 365 & 1091.4 & 1077.1 \\
\hline 346047 & 3.59 & 24.9 & 365 & 1310.4 & 1077.1 \\
\hline 346071 & 4.49 & 31.1 & 365 & 1638.9 & 1712.8 \\
\hline 346072 & 4.74 & 32.9 & 365 & 1730.1 & 1712.8 \\
\hline 346070 & 5.38 & 37.3 & 365 & 1963.7 & 1712.8 \\
\hline 346068 & 4.84 & 33.6 & 365 & 1766.6 & 2106.3 \\
\hline 346067 & 5.06 & 35.1 & 365 & 1846.9 & 2106.3 \\
\hline 346066 & 5.74 & 39.8 & 365 & 2095.1 & 2106.3 \\
\hline 346080 & 7.48 & 51.8 & 365 & 2730.2 & 2812.4 \\
\hline 346076 & 7.58 & 52.6 & 365 & 2766.7 & 2812.4 \\
\hline 346077 & 8.48 & 58.8 & 365 & 3095.2 & 2812.4 \\
\hline
\end{tabular}

Table B-3. Control and Background Data for Annual Average Radon Study; Control Set 3, 1985-1986 Data, Batch 18

\begin{tabular}{|c|c|c|c|c|c|}
\hline $\begin{array}{c}\text { Serial } \\
\text { Number } \\
\text { (pCI/L) }\end{array}$ & $\begin{array}{c}\text { Reported } \\
\text { Radon } \\
\text { (trk/mm²) }\end{array}$ & $\begin{array}{l}\text { Track } \\
\text { Density } \\
\text { (d) }\end{array}$ & $\begin{array}{c}\text { Reported } \\
\text { Time } \\
\text { (pCl-d/L) }\end{array}$ & $\begin{array}{c}\text { Calculated } \\
\text { Exposure } \\
\text { (pCl-d/L) }\end{array}$ & $\begin{array}{c}\text { Actual } \\
\text { Exposure }\end{array}$ \\
\hline \multicolumn{6}{|c|}{ Background Monitors } \\
\hline 346037 & 0.14 & 0.9 & 365 & 51.1 & 0 \\
\hline 346058 & 0.1 & 0.7 & 365 & 36.5 & 0 \\
\hline \multicolumn{6}{|c|}{ Exposed Monitors } \\
\hline 346078 & 5.94 & 41.2 & 365 & 2168.1 & 1468.36 \\
\hline 346079 & 6.76 & 46.9 & 365 & 2467.4 & 2959.12 \\
\hline 346081 & 8.73 & 60.5 & 365 & 3186.5 & 2959.12 \\
\hline 346082 & 7.15 & 49.6 & 365 & 2609.8 & 2959.12 \\
\hline
\end{tabular}


Table B-4. Control and Background Data for Annual Average Radon Study; Control Set 4, 1985-1986 Data, Batch 12

\begin{tabular}{|c|c|c|c|c|c|}
\hline $\begin{array}{l}\text { Serial } \\
\text { Number }\end{array}$ & $\begin{array}{c}\text { Reported } \\
\text { Radon } \\
\text { (pCl/L) }\end{array}$ & $\begin{array}{c}\text { Track } \\
\text { Density } \\
\text { (trk/mm²) }\end{array}$ & $\begin{array}{l}\text { Reported } \\
\text { Time } \\
\text { (d) }\end{array}$ & $\begin{array}{l}\text { Calculated } \\
\text { Exposure } \\
\text { (pCl-d/L) }\end{array}$ & $\begin{array}{c}\text { Actual } \\
\text { Exposure } \\
\text { (pCl-d/L) }\end{array}$ \\
\hline \multicolumn{6}{|c|}{ Background Monitors } \\
\hline 314204 & 0.61 & 0.4 & 30 & 18.3 & 0.0 \\
\hline 314206 & 0.10 & 0.1 & 30 & 3.0 & 0.0 \\
\hline 314210 & 0.70 & 0.4 & 30 & 21.0 & 0.0 \\
\hline 314217 & 1.99 & 1.2 & 30 & 59.7 & 0.0 \\
\hline \multicolumn{6}{|c|}{ Exposed Monitors } \\
\hline 314201 & 15.45 & 9.3 & 30 & 463.5 & 719.1 \\
\hline 314202 & 17.69 & 10.6 & 30 & 530.7 & 719.1 \\
\hline 314205 & 10.19 & 6.1 & 30 & 305.7 & 719.1 \\
\hline 314208 & 15.45 & 9.3 & 30 & 463.5 & 719.1 \\
\hline 314209 & 21.31 & 12.8 & 30 & 639.3 & 719.1 \\
\hline 314213 & 23.47 & 14.1 & 30 & 704.1 & 719.1 \\
\hline 314214 & 21.57 & 12.9 & 30 & 647.1 & 719.1 \\
\hline 314216 & 26.06 & 15.6 & 30 & 781.8 & 719.1 \\
\hline 314203 & 61.73 & 37.0 & 30 & 1851.9 & 1444.9 \\
\hline 314207 & 27.61 & 16.6 & 30 & 828.3 & 1444.9 \\
\hline 314211 & 30.46 & 18.3 & 30 & 913.8 & 1444.9 \\
\hline 314212 & 41.78 & 25.1 & 30 & 1253.4 & 1444.9 \\
\hline 314215 & 42.62 & 25.6 & 30 & 1278.6 & 1444.9 \\
\hline 314218 & 48.92 & 29.4 & 30 & 1467.6 & 1444.9 \\
\hline 314219 & 49.35 & 29.6 & 30 & 1480.5 & 1444.9 \\
\hline 314220 & 37.88 & 22.7 & 30 & 1136.4 & 1444.9 \\
\hline
\end{tabular}


Table B-5. Control and Background Data for Annual Average Radon Study; Control Set 5, 1986-1987 Data, Batch 24

\begin{tabular}{|c|c|c|c|c|c|}
\hline $\begin{array}{c}\text { Serial } \\
\text { Number }\end{array}$ & $\begin{array}{c}\text { Reported } \\
\text { Radon } \\
\text { (pCI/L) }\end{array}$ & $\begin{array}{c}\text { Track } \\
\text { Density } \\
\left(\text { trk } / \mathbf{m m}^{2}\right)\end{array}$ & $\begin{array}{c}\text { Reported } \\
\text { Time } \\
\text { (d) }\end{array}$ & $\begin{array}{l}\text { Calculated } \\
\text { Exposure } \\
\text { (pCi-d/L) }\end{array}$ & $\begin{array}{c}\text { Actual } \\
\text { Exposure } \\
\text { (pCl-d/L) }\end{array}$ \\
\hline \multicolumn{6}{|c|}{ Background Monitors } \\
\hline 314330 & 0.0 & 0.3 & 365 & 17.7 & 0.0 \\
\hline 314419 & 0.0 & 0.9 & 365 & 33.1 & 0.0 \\
\hline 314444 & 0.0 & 0.2 & 365 & 2.0 & 0.0 \\
\hline 314472 & 0.1 & 0.9 & 365 & 39.8 & 0.0 \\
\hline \multicolumn{6}{|c|}{ Exposed Monitors } \\
\hline 314318 & 2.4 & 21.0 & 365 & 907.6 & 1005.6 \\
\hline 314336 & 2.5 & 21.6 & 365 & 925.4 & 1005.6 \\
\hline 314351 & 2.6 & 22.6 & 365 & 974.5 & 1005.6 \\
\hline 314365 & 2.9 & 25.2 & 365 & 1084.7 & 1005.6 \\
\hline 314432 & 2.5 & 21.7 & 365 & 932.2 & 1005.6 \\
\hline 314450 & 2.3 & 20.2 & 365 & 871.9 & 1005.6 \\
\hline 314463 & 3.4 & 29.4 & 365 & 1268.3 & 1005.6 \\
\hline 314478 & 2.4 & 20.5 & 365 & 885.3 & 1005.6 \\
\hline 314327 & 1.1 & 9.6 & 365 & 410.1 & 387.7 \\
\hline 314342 & 1.0 & 9.2 & 365 & 394.5 & 387.7 \\
\hline 314354 & 1.3 & 11.8 & 365 & 506.0 & 387.7 \\
\hline 314425 & 1.5 & 12.9 & 365 & 550.6 & 387.7 \\
\hline 314437 & 1.1 & 9.6 & 365 & 412.3 & 387.7 \\
\hline 314458 & 1.0 & 9.0 & 365 & 390.0 & 387.7 \\
\hline 314467 & 1.3 & 11.7 & 365 & 499.4 & 387.7 \\
\hline 314483 & 1.4 & 12.2 & 365 & 523.9 & 387.7 \\
\hline
\end{tabular}


Table B-6. Control and Background Data for Annual Average Radon Study; Control Set 6, 1987-1988 Data, Batch 24

\begin{tabular}{|c|c|c|c|c|c|}
\hline $\begin{array}{l}\text { Serial } \\
\text { Number }\end{array}$ & $\begin{array}{c}\text { Reported } \\
\text { Radon } \\
\text { (pCl/L) }\end{array}$ & $\begin{array}{c}\text { Track } \\
\text { Denslty } \\
\text { (trk/mm })\end{array}$ & $\begin{array}{c}\text { Reported } \\
\text { Time } \\
\text { (d) }\end{array}$ & $\begin{array}{l}\text { Calculated } \\
\text { Exposure } \\
\text { (pCl-d/L) }\end{array}$ & $\begin{array}{l}\text { Actual } \\
\text { Exposure } \\
\text { (pCl-d/L) }\end{array}$ \\
\hline \multicolumn{6}{|c|}{ Background Monitors } \\
\hline 502391 & 0.2 & 1.3 & 360 & 57.7 & 0.0 \\
\hline 502445 & 0.1 & 0.7 & 360 & 28.7 & 0.0 \\
\hline 599947 & 0.2 & 1.3 & 360 & 57.7 & 0.0 \\
\hline 599954 & 0.1 & 0.6 & 360 & 24.3 & 0.0 \\
\hline \multicolumn{6}{|c|}{ Exposed Monitors } \\
\hline 502368 & 3.6 & 30.2 & 360 & 1300.2 & 1564.0 \\
\hline 502371 & 3.8 & 31.7 & 360 & 1365.0 & 1564.0 \\
\hline 502377 & 4.6 & 38.5 & 360 & 1658.8 & 1564.0 \\
\hline 502387 & 4.9 & 40.9 & 360 & 1762.1 & 1564.0 \\
\hline 502405 & 3.9 & 32.3 & 360 & 1394.0 & 1564.0 \\
\hline 502408 & 3.8 & . $\quad 31.4$ & 360 & 1353.8 & 1564.0 \\
\hline 599951 & 3.3 & 27.5 & 360 & 1186.5 & 1564.0 \\
\hline 502393 & 5.6 & 46.7 & 360 & 2010.7 & 1564.0 \\
\hline 502351 & 1.6 & 13.5 & 360 & 579.7 & 784.0 \\
\hline 502359 & 1.7 & 14.5 & 360 & 626.6 & 784.0 \\
\hline 502361 & 1.8 & 15.1 & 360 & 651.1 & 784.0 \\
\hline 502386 & 2.3 & 19.2 & 360 & 829.6 & 784.0 \\
\hline 502411 & 1.2 & 9.6 & 360 & 414.7 & 784.0 \\
\hline 502428 & 2.0 & 16.9 & 360 & 729.2 & 784.0 \\
\hline 502431 & 2.3 & 19.4 & 360 & 836.3 & 784.0 \\
\hline 502448 & 1.9 & 16.0 & 360 & 689.1 & 784.0 \\
\hline
\end{tabular}


Table B-7. Control and Background Data for Annual Average Radon Study; Control Set 7, 1988-1989 Data, Lot 1494

\begin{tabular}{|c|c|c|c|c|c|}
\hline $\begin{array}{l}\text { Serial } \\
\text { Number }\end{array}$ & $\begin{array}{c}\text { Reported } \\
\text { Radon } \\
\text { (pCI/L) }\end{array}$ & $\begin{array}{c}\text { Track } \\
\text { Density } \\
\text { (trk/mm²) }\end{array}$ & $\begin{array}{l}\text { Reported } \\
\text { Time } \\
\text { (d) }\end{array}$ & $\begin{array}{l}\text { Calculated } \\
\text { Exposure } \\
\text { (pCl-d/L) }\end{array}$ & $\begin{array}{c}\text { Actual } \\
\text { Exposure } \\
\text { (pCl-d/L) }\end{array}$ \\
\hline \multicolumn{6}{|c|}{ Background Monitors } \\
\hline 518722 & 0.10 & 1.3 & 365 & 51.8 & 0.00 \\
\hline 518746 & 0.1 & 1.3 & 365 & 53.1 & 0.00 \\
\hline 518665 & 0.20 & 2.2 & 365 & 88.5 & 0.00 \\
\hline \multicolumn{6}{|c|}{ Exposed Monitors } \\
\hline 518673 & 2.60 & 23.5 & 365 & 966 & 1440.00 \\
\hline 518636 & 2.70 & 24.3 & 365 & 997.4 & 1440.00 \\
\hline 518648 & 2.80 & 25 & 365 & 1024 & 1440.00 \\
\hline 518734 & 2.9 & 25.7 & 365 & 1055 & 1440.00 \\
\hline 518703 & 2.90 & 26.1 & 365 & 1070 & 1440.00 \\
\hline 518641 & 3.00 & 26.8 & 365 & 1098 & 1440.00 \\
\hline 518738 & 3.1 & 27.3 & 365 & 1119 & 1440.00 \\
\hline 518712 & 4.00 & 35.7 & 365 & 1463 & 1440.00 \\
\hline 518751 & 2.90 & 40.1 & 365 & 1645 & 2476.00 \\
\hline 518697 & 4.60 & 40.5 & 365 & 1661.4 & 2476.00 \\
\hline 518658 & 4.60 & 41.3 & 365 & 1692 & 2476.00 \\
\hline 518654 & 4.80 & 42.5 & 365 & 1742 & 2476.00 \\
\hline 518691 & 4.90 & 43.6 & 365 & 1787 & 2476.00 \\
\hline 518717 & 5.00 & 44.7 & 365 & 1835 & 2476.00 \\
\hline 518681 & 4.50 & 46.5 & 365 & 1907 & 2476.00 \\
\hline 518677 & 6.50 & 58 & 365 & 2379.6 & 2476.00 \\
\hline
\end{tabular}




\title{
Publications Issued by the
}

Technical Measurements Center

February 1990

Operated by

UNC Geotech

\author{
for \\ U.S. Department of Energy \\ Office of Remedial Action and Waste Technology \\ Idaho Operations Office \\ Grand Junction Projects Office
}


Number

G]/TMC-01*

2nd Edition

GJ/TMC-02

GI/TMC $-03^{*}$

GJ/TMC-04*

GJ/TMC-05*

GJ/TMC-06*

GJ/TMC-07*

GJ/TMC-08*

2nd Edition

GJ/TMC-09*

2nd Edition

GJ/TMC-10*

Letter Report

(unnumbered)

GJ/TMC-11*

GJ/TMC-12*

GJ $/ \mathrm{TMC}-13^{*}$
Title (Authors)

Field Calibration Facilities for Environmental Measurement of Radium, Thorium, and Potassium. (W. D. Steele and D. C. George)

Review of Selected DOE Remedial Action Field Measurement Procedures for the Summer of 1982. (TMC Staff)

Abbreviated Total-Count Logging Procedures for Use in Remedial Action.

(D. C. George and R. K. Price)

Evaluation of Methods for the Estimation of Indoor Radon Daughter Concentrations for Remedial Action Programs. (G. H. Langner, Jr., J. C. Pacer, V. G. Johnson, and M. A. Gillings)

Feasibility Study of the Prompt Pb-214, Bi-214 Gamma Method for Determining Radon Migration Through Tailings. (L. R. Stieff, The Stieff Research and Development Co., Inc., Kensington, Maryland)

Surface Gamma-Ray Measurement Protocol. (S. J. Marutzky, W. D. Steele, and B. N. Key)

Procedures for Field Chemical Analyses of Water Samples. (N. Korte and D. Ealey)

Procedures for the Collection and Preservation of Groundwater and Surface Water Samples and for the Installation of Monitoring Wells. (N. Korte and P. Kearl)

Protocol for the Estimation of Average Indoor Radon-Daughter Concentrations. (G. H. Langner, Jr. and J. C. Pacer)

Deoelopment of Solid Radium-226 Reference Materials. (R. B. Chessmore and P. R. Engelder)

Supplemental Measurements for Polonium-210 and Lead-210 in TMC Radium Reference Material (insert to GJ/TMC-10). (S. Donivan)

Procedure Manual for the Estimation of Average Indoor Radon-Daughter Concentrations Using the Radon Grab-Sampling Method. (J. L. George)

Procedure Manual for the Estimation of Average Indoor Radon-Daughter Concentrations Using the Radon Progeny Integrating Sampling Unit (RPISU) Method. (G. H. Langner, Jr.)

Procedures for Sampling Radium-Contaminated Soils. (H. L. Fleischhauer)

Available from National Technical Information Service, U.S. Department of Commerce, 5285 Port Royal Road, Springfield, Virginia 22161, (703) 487-4600. 
Number

GJ/TMC-14*

GJ/TMC-15*

GJ/TMC-16*

GI/TMC-17*

GJ/TMC-18*

GJ/TMC-19*

GJ/TMC-20

GJ/TMC-22*

Letter Report

(unnumbered)

GJ/TMC-23

GJ/TMC-24*

GJ/TMC-25*

GJ/TMC-26*

GJ $/ \mathrm{TMC}-27^{*}$
Title (Authors)

Procedures for Reconnaissance Stream-Sediment Sampling.

(H. L. Fleischhauer and P. R. Engelder)

A Feasibility Study of the Use of Nuclear-Emulsion Techniques in the Study of Drill Core and Water Samples from the Monticello Mill, Monticello, Utah.

(L. R. Stieff, The Stieff Research and Development Co., Inc., Kensington, Maryland)

Test and Evaluation of Selected Instruments for Surface Gamma-Ray Measurements. (B. N. Key)

Calibration-Pad Parameter Assignments for In-Situ Gamma-Ray Measurements of Radium, Thorium, and Potassium. (D. C. George, E. F. Novak, and R. K. Price)

Operating Manual for the Radon-Daughter Chamber. (G. H. Langner, Jr., and T. Nelson)

Laboratory Intercomparison of Analytical Results on Samples Contaminated by Uranium Mill Tailings. (N. Korte, M. Hollenbach, and S. Donivan)

Radon-Daughter Chamber Instrumentation System Reference Manual. (L. Johnson and R. Showalter)

Development of Solid Thorium-232 Reference Materials. (P. R. Engelder, S. Donivan, and R. B. Chessmore)

Supplemental Measurements for Radium-226 and Potassium-40 in TMC Thorium Reference Material (insert to GJ/TMC-22). (S. Donivan)

Gamma-Ray Instrument Calibration Comparison Workshop. (W. D. Steele, D. C. George, and J. L. Burnham)

Comparison of In-Situ and Laboratory Measurement Methods for Radium-226 in Soils. (S. J. Marutsky, H. L. Fleischhauer, and P. R. Engelder)

Interlaboratory Radon-Daughter Measurement Comparison Workshop: 9-12 September 1985. (M. Pearson)

Field Study of Indoor Average Radon-Daughter Estimation Methods. (J. L. George and G. H. Langner, Jr.)

Assessment of Mobile Gamma-Scanning Van Activities in Edgemont, South Dakota. (U.S. Department of Energy Task Force)

\footnotetext{
"Available from National Technical Information Service, U.S. Department of Commerce, 5285 Port Royal Road, Springfield, Virginia 22161, (703) 487-4600.
} 
Number

GJ/TMC-28*

UNC/GJ-29(TMC)*

UNC/GJ-31(TMC)*

UNC/GJ-32(TMC)*

UNC/GJ-33(TMC)*

UNC/GJ-34(TMC)*

UNC/GJ-35(TMC)*

UNC/GJ-36 (TMC)*

UNC/GJ-TMC-1

UNC/GJ-TMC-2

UNC/GJ-37(TMC)*

UNC/GJ-38 (TMC)*

$\mathrm{UNC} / \mathrm{GJ}-39$ (TMC)*

UNC/GJ-40(TMC)*

UNC/GJ-41(TMC)*

UNC/GJ-42(TMC)*
Title (Authors)

Interim Results of the Prompt Alpha-Track Radon Detector Study.

(J. L. George and G. H. Langner, Jr.)

Comparison of Radon and Radon-Daughter Grab Samples Obtained During the Winter and Summer. (K. E. Karp)

Investigation of the Hammer-Gamma Measurement Technique: A Feasibility Study. (R. Showalter)

Construction and Characterization of the TL/TH Thorium Calibration Pads.

(W. Douglass Steele)

Validation of the Prompt Alpha-Track Method. (J. L. George and G. H.

Langner, Jr.)

Validation of the Abbreviated Radon Progeny Integrating Sampling Unit (RPISU) Method for Mesa County, Colorado. (G. H. Langner, Jr.)

Construction and Testing of a Blower-Door Assembly for Regulation of Air Pressure Within Structures. (W. Douglass Steele)

Uranium Reference Materials. (S. Donivan and R. B. Chessmore)

Determination of Radon Sources at Four Vicinity Properties in Edgemont, South Dakota. (K. E. Karp)

Radon-Daughter Grab-Sampling Technical Exchange Meeting 14-17 April 1986. (M. D. Pearson)

Soil-Based Uranium Disequilibrium and Mixed Uranium-Thorium Series Radionuclide Reference Materials. (S. Donivan and R. B. Chessmore)

The Use of Atomic Absorption Spectroscopy to Measure Arsenic, Selenium, Molybdenum, and Vanadium in Water and Soil Samples From Uranium Mill Tailings Sites. (M. H. Hollenbach)

Procedure Manual for the Estimation of Average Indoor Radon-Daughter Concentrations Using the Electronic Radon Progeny Integrating Sampling Unit (ERPISU) Method. (M. D. Pearson)

Procedure Manual for the Estimation of Average Indoor Radon-Daughter Concentrations Using the Filtered Alpha-Track Method. (J. L. George)

Detecting Buried Radium Contamination Using Soil-Gas and Surface-Flux Radon Measurements. (K. E. Karp)

Exposure-Rate Calibration Using Large-Area Calibration Pads. (E.F. Novak)

"Available from National Technical Information Service, U.S. Department of Commerce, 5285 Port Royal Road, Springfield, Virginia 22161, (703) 487-4600. 
Number

UNC/GJ-43(TMC)*

UNC/GJ-TMC-3*

UNC/GJ-TMC-4*

UNC/GJ-44(TMC)*

UNC/GJ-45(TMC)*

UNC/GJ-46(TMC)*

UNC/GJ-47(TMC)*

UNC/GJ-48(TMC)*

UNC/GJ-TMC-5*

UNC/GJ-TMC-6*

UNC/GJ-49(TMC)*

UNC/GJ-50(TMC)*
Title (Authors)

Year-Long Comparison of Two Techniques to Monitor Outdoor Radon Concentrations at Shiprock, New Mexico. (E. F. Novak)

Procedures, Analysis, and Comparison of Groundwater Velocity Measurement Methods for Unconfined Aquifers. (P. M. Kearl, J. J. Dexter, and J. E. Price)

Supplement to Procedures, Analysis, and Comparison of Groundwater Velocity Measurement Methods for Unconfined Aquifers. (R. J. Zinkl and P. M. Kearl)

Evaluation of the Performance Characteristics of Radon and Radon-Daughter Concentration Measurement Devices Under Controlled Environmental Conditions. (M. D. Pearson)

Construction and Characterization of the RH/RL Radium Calibration Pads. (W. D. Steele, S. J. Marutzky, and J. W. Dickerson)

Performance of Diffusion-Barrier Scintillation Cells Under a Variety of Controlled Environmental Conditions. (R. R. Spangler and G. H. Langner, Jr.)

-Validation of the Diffusion-Barrier Charcoal Canister Method. (D. E. Martz, J. L. George, S. T. Mamich, and G. H. Langner, Jr.)

Field Method for Determining Thorium-230 in Soils. (G. Dechant)

Development of Electret Technology to Measure Indoor Radon-Daughter Concentrations (Stieff Research and Development Co., Inc., Kensington, Maryland)

Radon-Daughter Grab-Sampling Technical Exchange Meeting April 10-14, 1989. (M. D. Pearson)

Gamma and Beta Logging of Underground Sewer and Process Lines. (M. J. Rangel, D. E. Martz, and G. H. Langner, Jr.)

Variation in the Annual Average Radon Concentration Measured in Homes in Mesa County, Colorado. (A. S. Rood, J. C. George, and G. H. Langner, Jr.)

"Available from National Technical Information Service, U.S. Department of Commerce, 5285 Port Poyal Road, Springfield, Virginia 22161, (703) 487-4600. 